\title{
Demonstration of Integrated Postlrradiation Process Steps for Multikilogram Amounts of Low- and High-Burnup Used Nuclear Fuels
}

Approved for public release.

Distribution is unlimited
E. D. Collins
D. E. Benker
L. K. Felker
P. D. Bailey
B. B. Spencer
G. D. Del Cul
R. T. Jubin
R. J. Vedder
E. A. Walker
S. L. Voit

October 2020 


\section{DOCUMENT AVAILABILITY}

Reports produced after January 1, 1996, are generally available free via US Department of Energy (DOE) SciTech Connect.

Website www.osti.gov

Reports produced before January 1, 1996, may be purchased by members of the public from the following source:

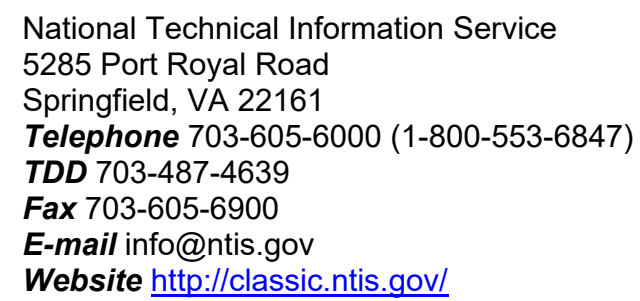

Reports are available to DOE employees, DOE contractors, Energy Technology Data Exchange representatives, and International Nuclear Information System representatives from the following source:

Office of Scientific and Technical Information

PO Box 62

Oak Ridge, TN 37831

Telephone 865-576-8401

Fax 865-576-5728

E-mail reports@osti.gov

Website http://www.osti.gov/contact.html

This report was prepared as an account of work sponsored by an agency of the United States Government. Neither the United States Government nor any agency thereof, nor any of their employees, makes any warranty, express or implied, or assumes any legal liability or responsibility for the accuracy, completeness, or usefulness of any information, apparatus, product, or process disclosed, or represents that its use would not infringe privately owned rights. Reference herein to any specific commercial product, process, or service by trade name, trademark, manufacturer, or otherwise, does not necessarily constitute or imply its endorsement, recommendation, or favoring by the United States Government or any agency thereof. The views and opinions of authors expressed herein do not necessarily state or reflect those of the United States Government or any agency thereof. 


\section{DEMONSTRATION OF INTEGRATED POSTIRRADIATION PROCESS STEPS FOR MULTIKILOGRAM AMOUNTS OF LOW- AND HIGH-BURNUP USED NUCLEAR FUELS}
E. D. Collins
D. E. Benker
L. K. Felker
P. D. Bailey
B. B. Spencer
G. D. Del Cul
R. T. Jubin
R. J. Vedder
E. A. Walker
S. L.Voit

Date Published: October 2020

\section{Prepared by}

OAK RIDGE NATIONAL LABORATORY

Oak Ridge, TN 37831-6283

managed by

UT-BATTELLE, LLC

for the

US DEPARTMENT OF ENERGY

under contract DE-AC05-00OR22725 



\section{CONTENTS}

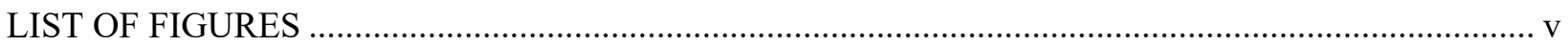

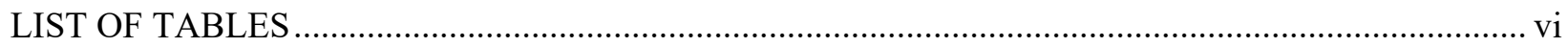

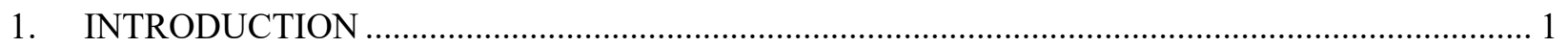

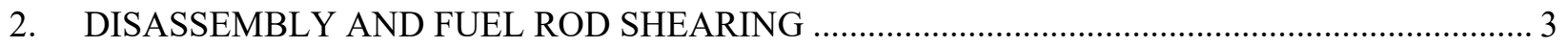

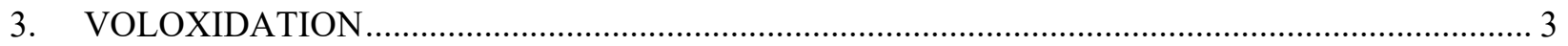

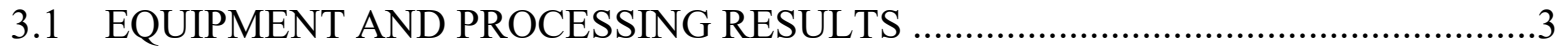

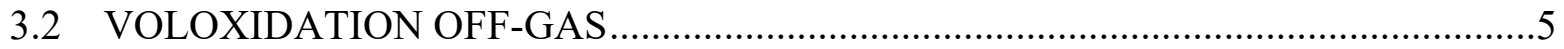

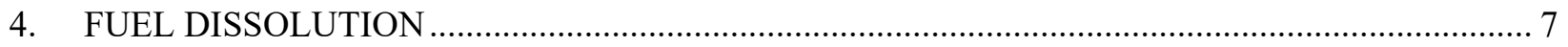

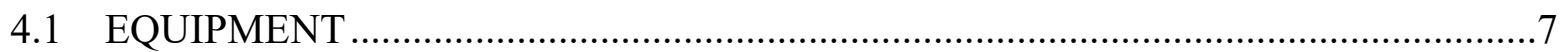

4.2 DISSOLUTION PROCEDURES ....................................................................... 9

4.3 DISSOLUTION RESULTS AND COMPARISONS ...............................................

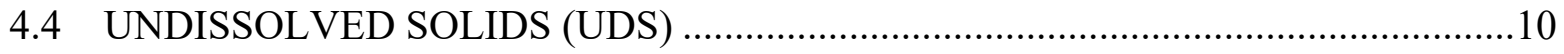

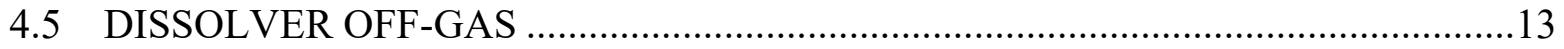

4.6 FRESH AND USED FUEL CLADDING COMPARISONS ................................... 14

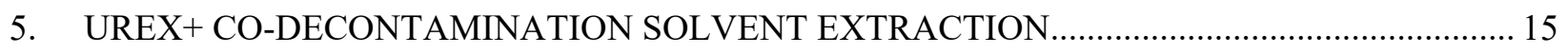

5.1 SOLVENT EXTRACTION EQUIPMENT IN THE ORNL REDC..........................15

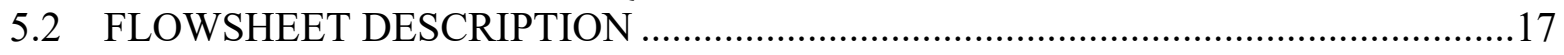

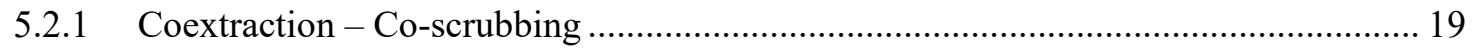

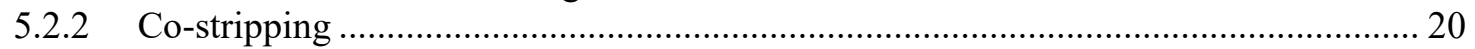

5.2.3 Component Distribution and Co-Stripped U-Pu-Np Product Decontamination

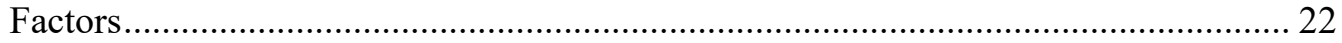

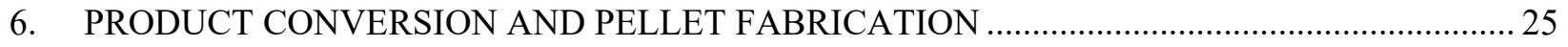

6.1 THE MODIFIED DIRECT DENITRATION (MDD) PROCESS AND

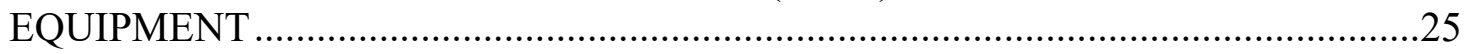

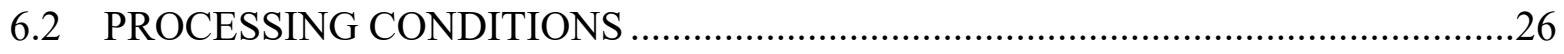

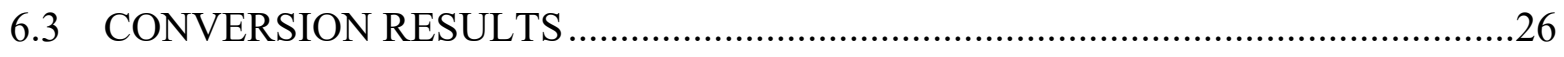

6.4 REDUCTION of $\mathrm{UO}_{3}$, PELLET PRESSING, AND SINTERING .........................277

6.5 PELLET MICROSTRUCTURAL CHARACTERIZATION .................................29

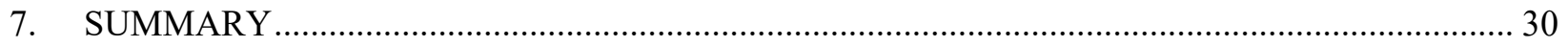

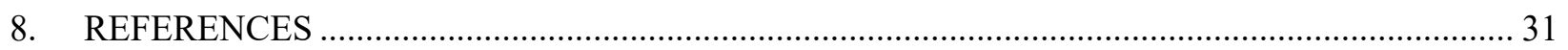





\section{LIST OF FIGURES}

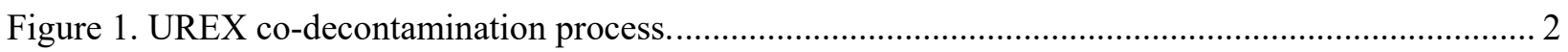

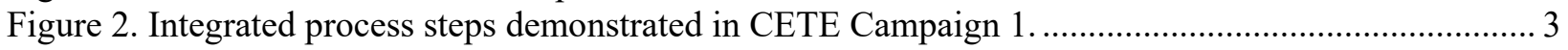

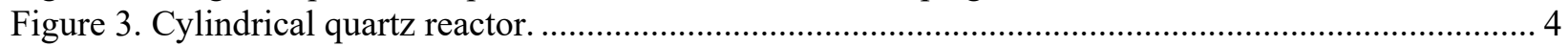

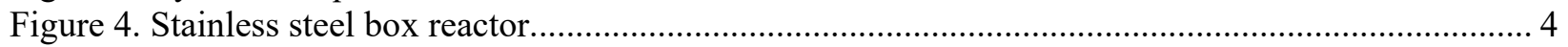

Figure 5. Schematic design of batch stainless steel rotary voloxidization reactor.................................... 5

Figure 6. Simplified off-gas trapping system for tests with Dresden-1 fuel. ............................................ 6

Figure 7. Picture of the rack containing the dissolution equipment....................................................... 8

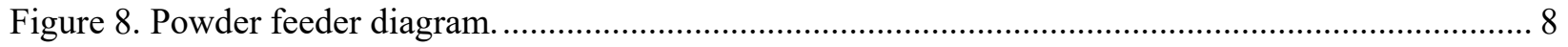

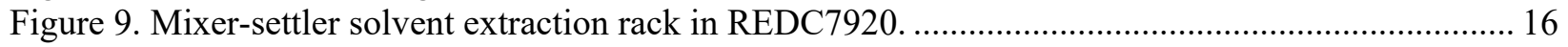

Figure 10. Close-up view of a mixer-settler in operation $6 \mathrm{~b}$ feed solution clarification.......................... 16

Figure 11. CETE Campaign 1-Dresden-1 1 BWR UNF (24 GWd/MT, 32 y decay).......................... 18

Figure 12. CETE Campaign 2-North Anna PWR UNF (65 GWd/MT, 5 y decay)................................ 19

Figure 13. Measured aqueous phase concentration profiles for co-extraction-co-scrub contactor

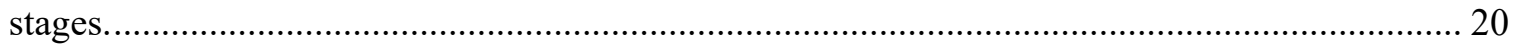

Figure 14. Plutonium concentration factors calculated by SEPHIS..................................................... 21

Figure 15. Measured concentration profiles for partitioning and partial partitioning contactor

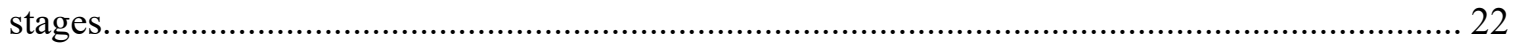

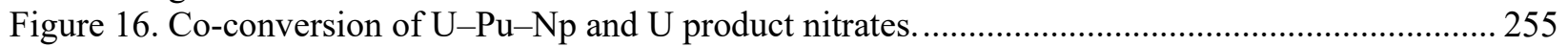

Figure 17. MDD-produced U-Pu-Np oxide from CETE Campaign 1 ................................................. 27

Figure 18. SEM image of reduced MDD U-Pu-Np product at $1,000 \times$ magnification.............................. 28

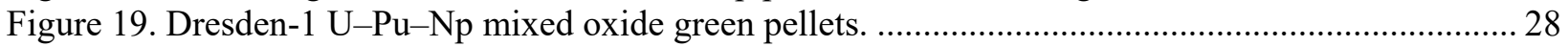

Figure 20. Axial (left) and radial (right) cross sections of sintered MDD pellets...................................29

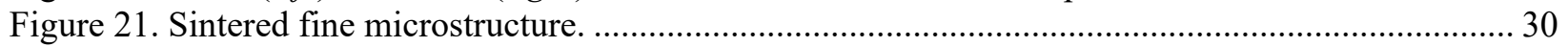




\section{LIST OF TABLES}

Table 1. Bounding of UNF integrated process demonstrations in CETE. .............................................. 2

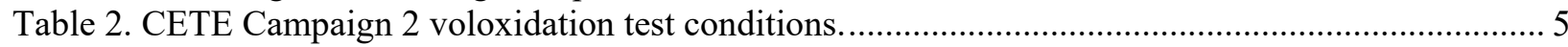

Table 3. Summary of analysis of Campaign 1 voloxidation off-gas traps.......................................... 7

Table 4. Comparison of measured dissolver solution components with ORIGEN predictions.................. 10

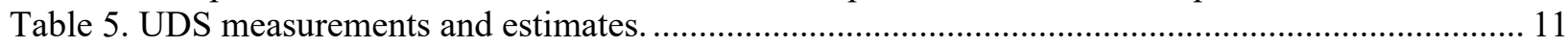

Table 6. Comparison of UDS vs burnup from the $\mathrm{HNO}_{3}$ dissolution of used LWR oxide fuels ${ }^{(\mathrm{a})} \ldots \ldots \ldots \ldots . . . .12$

Table 7. Distribution of noble metals and actinide elements between dissolver solutions and UDS. $^{(a)}$

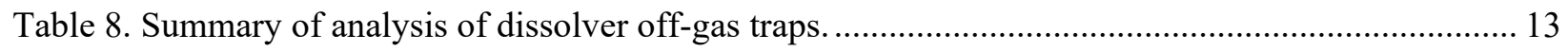

Table 9. Representative composition of fresh (unirradiated) $\mathrm{Zr}$ alloy-cladding. .................................... 14

Table 10. Typical radioactive component concentrations in UNF cladding.......................................... 14

Table 11. UREX co-decontamination - partial partitioning end stream component distribution............... 23

Table 12. UREX co-decontamination $\mathrm{U}-\mathrm{Pu}-\mathrm{Np}$ product decontamination factors. ${ }^{\text {(a) }}$............................ 24

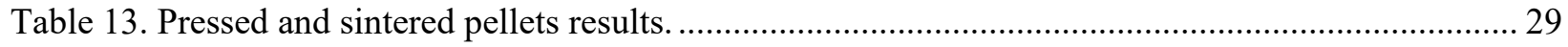




\section{INTRODUCTION}

During the decade 2000-2010, the US Department of Energy Office of Nuclear Energy (DOE-NE) sponsored research and development (R\&D) on the advanced, closed nuclear fuel cycle, including postirradiation processing of used fuels, recovery of separated components, and preparation of recycle nuclear fuels. During the period 2007-2010, kilogram-scale demonstrations of the integrated processing steps were performed for actual light water reactor (LWR) used nuclear fuels (UNF). These integrated processing demonstrations were called "the Coupled-End-to-End" (CETE) campaigns and were associated with the Global Nuclear Energy Partnership program, which ran concurrently. The demonstrations were carried out in the shielded hot cells and associated gloveboxes located in the Irradiated Fuels Examination Laboratory (IFEL) and the Radiochemical Engineering Development Center (REDC) at the Oak Ridge National Laboratory (ORNL). Limited circulation program reports and a few technical papers were issued [Refs. 1,2]. The subject document provides a comprehensive summary of results, technical comparisons, and conclusions obtained from the demonstration campaigns and subsequent associated R\&D.

Initial associated R\&D at ORNL's REDC began in the late 1970s and continued through the1980s as part of the DOE-NE Consolidated Fuel Recycle Program (CFRP), using kilogram amounts of LWR used fuel to develop and test processes for processing fast breeder reactor (FBR) used fuel. Processes for iodine removal from dissolver solutions [Ref. 3] and U-Pu co-processing solvent extractions were developed and demonstrated [Ref. 4]. The solvent extraction tests were made using used fuel from the $\mathrm{H}$. B. Robinson-2 pressurized water reactor (PWR) and from the Dresden-1 boiling water reactor (BWR). During these tests, conditions for the successful use of hydroxylamine nitrate (HAN) as the reducing agent for $\mathrm{Pu}(\mathrm{IV})$ to $\mathrm{Pu}$ (III) were determined, thus enabling decreased waste generation since subsequent decomposition of the HAN is to gasses and water. These developments culminated in 1986 with demonstrations of solvent extraction flowsheets using high-burnup used fuel from the Fast Flux Test Reactor, a fast breeder demonstration reactor [Ref. 5]. These demonstrations showed that FBR used fuels containing higher Pu concentrations than LWR used fuels, can be successfully processed by means of aqueous-based solvent extraction processes, such that the same processing facility can be used to process either LWR or FBR used fuels.

During the 1990s, there was a shift in R\&D focus toward waste management issues, but fuel cycle process development resumed in the early 2000s as part of the DOE-NE Advanced Fuel Cycle Initiative (AFCI) program. This resulted in development of the UREX+ Co-decontamination solvent extraction process Figure 1) [Ref. 6], which was subsequently used in the CETE campaigns for separating the bulk $\mathrm{U}$ and a $\mathrm{U}-\mathrm{Pu}-\mathrm{Np}$ product containing all of the $\mathrm{Pu}$ and $\mathrm{Np}$, plus a controlled portion of $\mathrm{U}$ necessary to minimize the safeguards attractiveness level and convert to oxide or metal recycle fuel for either or both LWRs and FBRs. 


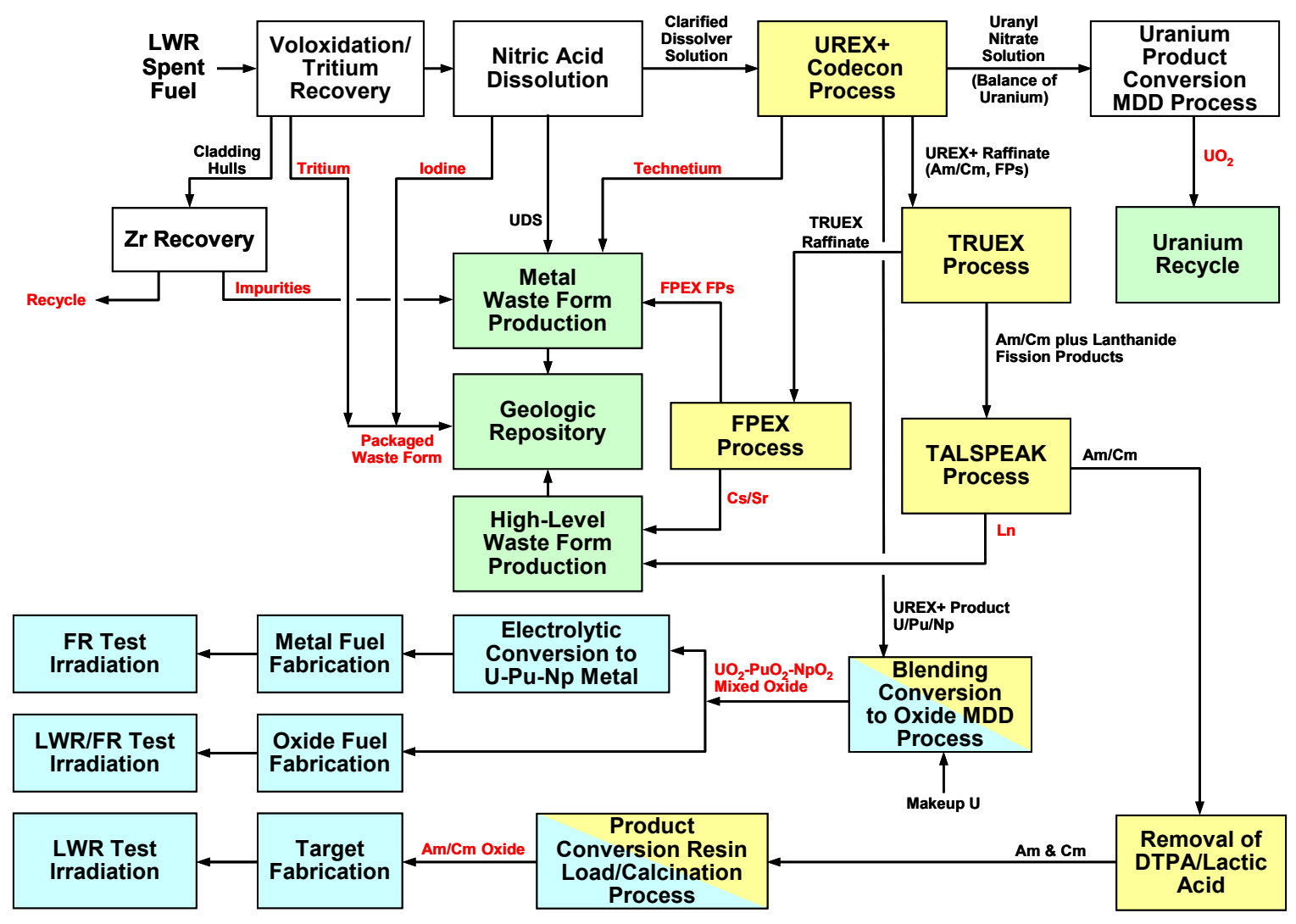

Figure 1. UREX co-decontamination process.

The AFCI program culminated with the integrated process demonstrations of the CETE campaigns, using kilogram amounts of low-burnup, long-decayed used fuel from the Dresden-1 BWR in CETE Campaign 1, and high-burnup, short-decayed used fuel from the North Anna PWR in Campaign 2. These demonstrations bracketed typical LWR used fuels being generated currently, as illustrated in Table 1, and allowed some comparison of the effects of burnup, decay time, and cladding types.

Table 1. Bounding of UNF integrated process demonstrations in CETE Campaigns 1 and 2.

\begin{tabular}{|l|l|l|l|}
\hline & \multicolumn{1}{|c|}{ Lower bound } & \multicolumn{1}{c|}{ Typical } & \multicolumn{1}{c|}{ Upper bound } \\
\hline Reactor and type & Dresden-1 BWR & BWRs/PWRs & North Anna PWR \\
\hline Burnup (GWd/MT) & 24 & $45-55$ & $\sim 65$ \\
\hline Decay time (y) & 32 & $5-10$ & 5 \\
\hline Cladding type & Zircaloy-2 & Zircaloy-4/High Nb & High Nb \\
\hline
\end{tabular}

The integrated process steps and interface feed adjustments demonstrated in CETE Campaign 1 in June 2007 are shown in Figure 2 and were described in detail in Ref. 1. Campaign 2, performed in 2009, did not include the high-level waste partitioning process steps, TRUEX, TALSPEAK, and FPEX. Newer technologies have been developed for high-level waste partitioning since 2009; therefore, the high-level waste partitioning process steps are not discussed further in this report. 


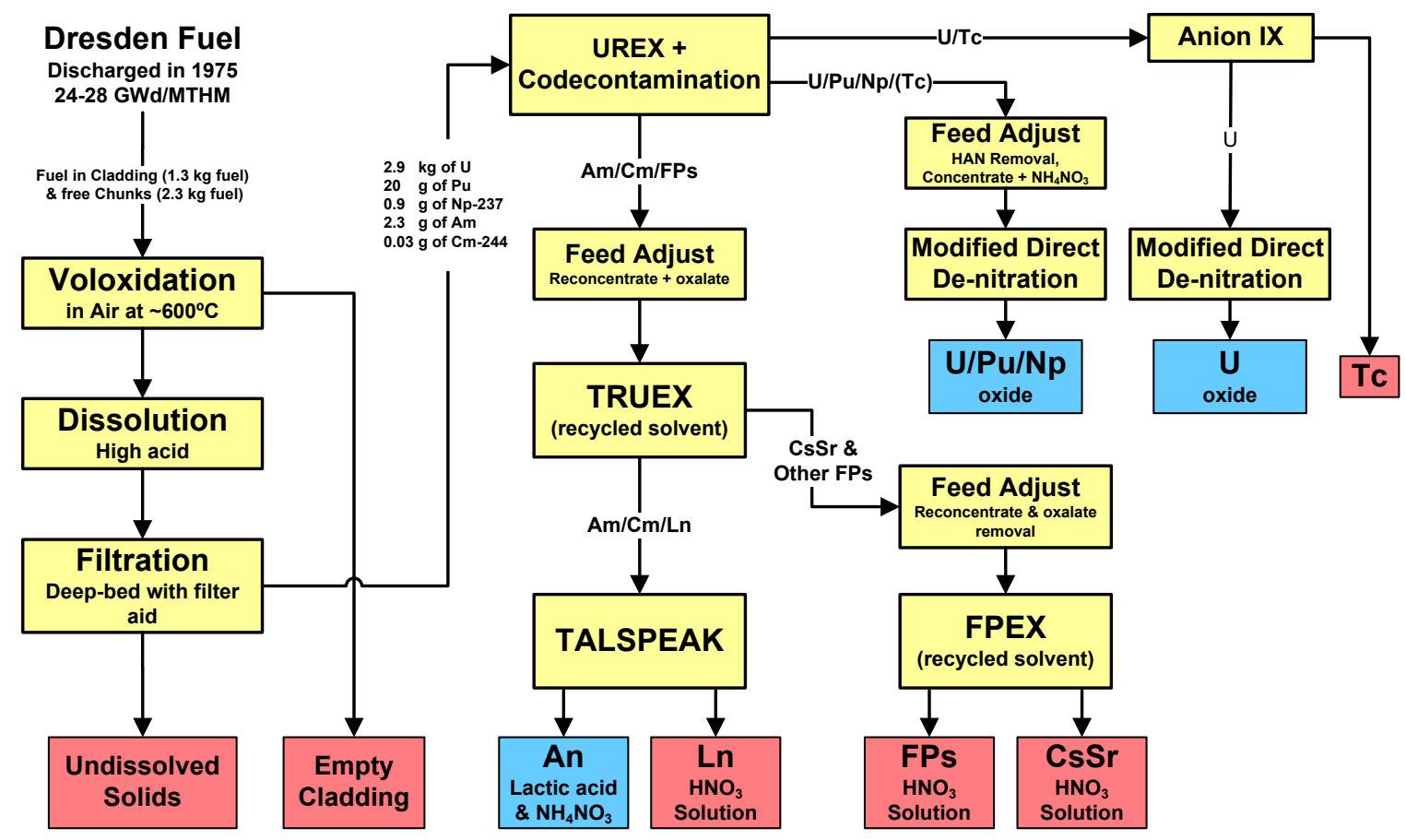

Figure 2. Integrated process steps demonstrated in CETE Campaign 1.

\section{DISASSEMBLY AND FUEL ROD SHEARING}

Used fuel assemblies were debundled, and the full-length fuel rods were cropped before shipping to ORNL. The fuel rod segments were sheared into smaller lengths in the ORNL IFEL hot cell using a rerod cutter, modified for remote use as a single-pin shear.

Approximately $50 \mathrm{~kg}$ of the Dresden-1 used fuel was sheared at the IFEL hot cell facility into segments $\sim 2$ in. long in early FY 1980, packaged in quart-sized paint cans, each containing $\sim 2 \mathrm{~kg}$ of used fuel, plus cladding, and then shipped to the REDC hot cell facility. Most of this fuel was used for earlier CFRP and AFCI R\&D programs. Most of the remainder (3.6 kg of used fuel) was used as feed to the CETE Campaign 1 voloxidization process step. That dry process is used primarily to remove tritium to the offgas traps and avoid introducing it into the dissolution and subsequent aqueous solutions in the form of tritiated water.

During CETE Campaign 2, North Anna PWR used fuel rods and some Surry-2 used fuel rods were sheared into segments $\sim 1$ in. long and then voloxidized in the IFEL hot cell. The amounts produced are listed in Table 2 below.

\section{VOLOXIDATION}

\subsection{EQUIPMENT AND PROCESSING RESULTS}

The basic voloxidation process (oxidation using air at $450-600^{\circ} \mathrm{C}$ ) was used in CETE Campaign 1 using sheared Dresden-1 used fuel rod segments. Since the fuel had been shipped to the REDC before voloxidation, temporary voloxidation reactors were installed in the REDC hot cell to process $3.6 \mathrm{~kg}$ of the remaining $\sim 4.2 \mathrm{~kg}$ of the original $\sim 50 \mathrm{~kg}$ of Dresden- 1 fuel rod segments. As described above, the fuel had been sheared into segments measuring $\sim 2$ in. in length at the IFEL in 1980, packaged into quart cans, 
each containing $\sim 2 \mathrm{~kg}$ of fuel (the capacity of the REDC used fuel dissolver tank), and transported to REDC for subsequent R\&D tests. When the CETE Campaign 1 began in $2007, \sim 60 \%$ of the fuel was found to have fragmented and fallen out of the cladding hulls, either during the initial shearing, transportation, long storage, or subsequent handling. About $2.3 \mathrm{~kg}$ of loose fuel fragments were separated from $\sim 1.9 \mathrm{~kg}$ of fuel still in the clad fuel rod segments. Part of the clad fuel rod segments (containing $\sim 0.6 \mathrm{~kg}$ of fuel) was set aside for future R\&D.

Two temporary batch reactors were fabricated to voloxidize the Dresden-1 used fuel at REDC. A cylindrical quartz glass reactor (Figure 3) was used in an existing vertical tube furnace to process the clad fuel rod segments (a total of $1.3 \mathrm{~kg}$ of fuel in several batches of $200 \mathrm{~g}$ fuel [six segments] per batch). A stainless steel rectangular reactor (Figure 4) was used in an existing box furnace to process a total of $2.3 \mathrm{~kg}$ of loose fuel fragments (two batches). Each reactor contained a perforated plate to hold the segments and fragments while allowing the voloxidized fuel powder to pass through to a collection chamber. Also, each reactor contained an air-injection tube and thermocouple well at the bottom of the reactor and an off-gas vent tube from the top of the reactor.

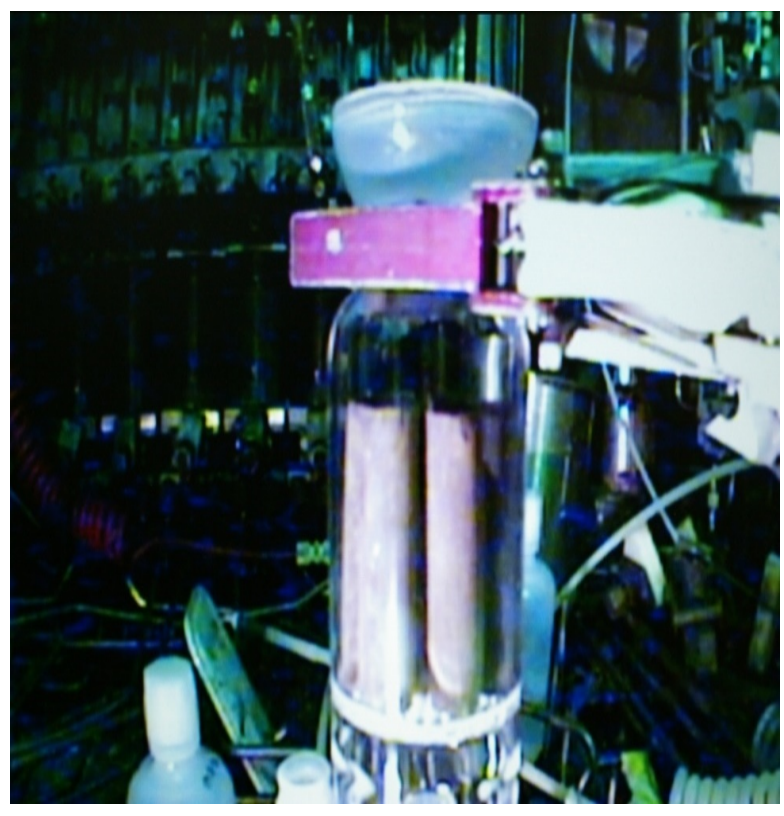

Figure 3. Cylindrical quartz glass reactor.

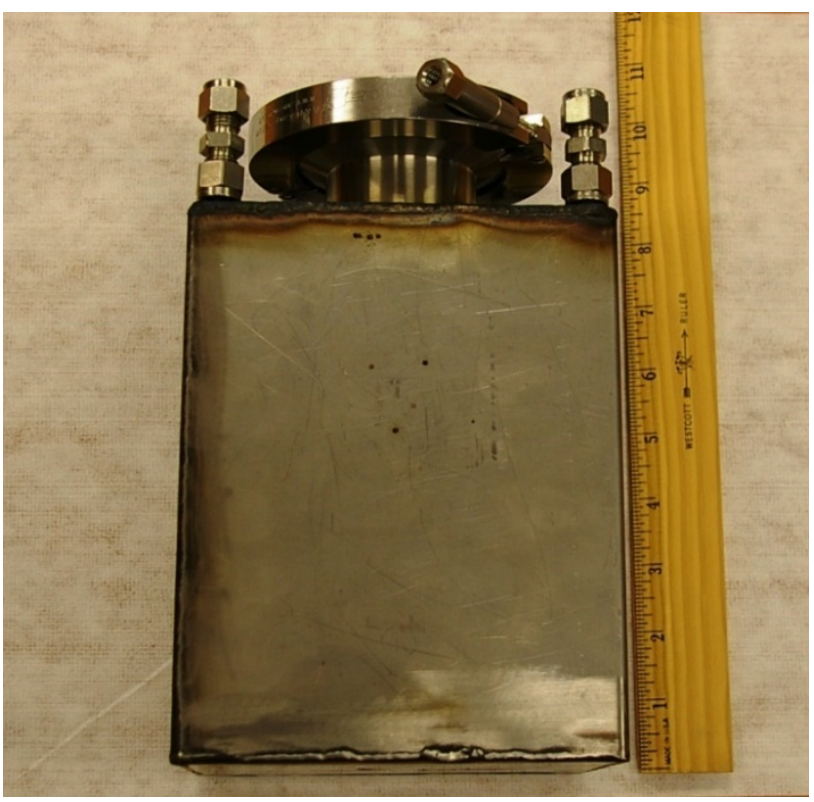

Figure 4. Stainless steel box reactor.

The CETE Campaign 1 voloxidations were done in air heated to $600^{\circ} \mathrm{C}$. The reaction rate was generally limited by the air feed rate, and the processing time per batch ranged from 6 to $12 \mathrm{~h}$. The average weight gain from the voloxidzation for the cladded fuel was 3.4\%, and it was 3.1\% for the loose fuel fragments. When compared to the weight gain for conversion of $\mathrm{UO}_{2}$ to $\mathrm{U}_{3} \mathrm{O}_{8}$ of $4.0 \%$ (without correcting for fission product or other actinide changes), the Campaign 1 conversions of the $\mathrm{UO}_{2}$ to $\mathrm{U}_{3} \mathrm{O}_{8}$ were $86 \%$ in the cylindrical quartz reactor and $78 \%$ in the stainless steel rectangular reactor. Visual examination showed that the finely divided fuel powder was effectively released from the cladding. The cladding hulls had been mechanically removed from the fuel powder using screens, either internally in the voloxidizer reactor or in a separate apparatus.

For CETE Campaign 2, a $5 \mathrm{~kg}$ scale, stainless steel, batch rotary voloxidization reactor (Figure 5) was designed, built, and installed in an IFEL hot cell. This reactor was mounted on a tilting platform to enable loading and unloading from a vertical position and to an inclined or horizontal position for rotational contacting of the fuel and oxidation gas during the reaction [Ref. 7]. 


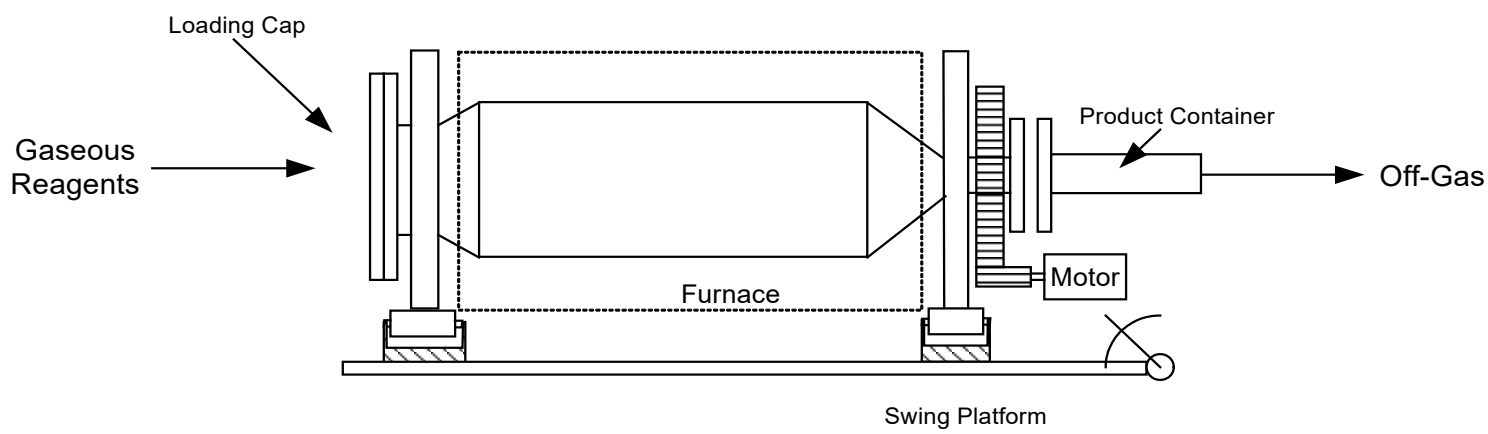

Figure 5. Schematic design of batch stainless steel rotary voloxidization reactor.

The oxidation reaction rate and extent were measured by the rate of ${ }^{85} \mathrm{Kr}$ evolution and $\mathrm{O}$ depletion from the oxidizing gas. In each test the reaction began at $\sim 100^{\circ} \mathrm{C}$ and required $\sim 12$ hours to complete in air, but only 4 hours in $\mathrm{O}$. In addition to tritium, $10-50 \%$ of the $\mathrm{Kr}$ was released from the fuel to the off-gas.

The fuel powder had very fine particle size, flowed readily, and could be mechanically separated from the cladding hulls. However, it was dusty and had to be rinsed from the cladding hulls.

Three batches of sheared UNF were voloxidized in various conditions (Table 2) in batches ranging from $\sim 1$ to $\sim 2 \mathrm{~kg}$ of heavy metal fuel in each batch during CETE Campaign 2 . Initially, a perforated internal basket was used to separate cladding hulls from the voloxidized $\mathrm{U}_{3} \mathrm{O}_{8}$ powder during the reaction, but insufficient tumbling occurred. The basket was removed, and the outer drum was equipped with lifting vanes to fix the problem.

Table 2. CETE Campaign 2 voloxidation test conditions.

\begin{tabular}{|c|c|c|c|c|c|c|}
\hline \multirow[b]{2}{*}{ Batch } & \multirow[b]{2}{*}{ Fuel Source } & \multirow{2}{*}{$\underset{\text { (GWd/MT) }}{\text { Burnup }}$} & \multicolumn{3}{|c|}{ Segment } & \multirow{2}{*}{$\begin{array}{c}\text { Operation } \\
\text { temperature } \\
\left({ }^{\circ} \mathrm{C}\right)\end{array}$} \\
\hline & & & $\begin{array}{l}\text { Batch size } \\
\left(\mathrm{kg}^{\mathrm{a}}\right) /\left(\mathrm{kg}^{\mathrm{b}}\right)\end{array}$ & $\begin{array}{c}\text { Length } \\
\text { (in.) }\end{array}$ & Oxidation gas & \\
\hline 1 & Surry-2 & 36 & $1.223 / 1.704$ & 1.0 & Air & 500 \\
\hline 2 & North Anna & $63-70$ & $2,071 / 2.885$ & 0.88 & Air & 600 \\
\hline 3 & North Anna & $63-70$ & $2.012 / 2.803$ & 0.88 & Oxygen & 600 \\
\hline
\end{tabular}

(a) Heavy metal basis

(b) Total fuel (oxide + cladding) basis

The three batches of voloxidized fuel and cladding hulls were packaged and transported to REDC for dissolution and component separations. Only a portion of the North Anna fuel and none of the Surry fuel was used in Campaign 2 tests at the REDC.

\subsection{VOLOXIDATION OFF-GAS}

Off-gases from the voloxidations in the cylindrical quartz reactor during CETE Campaign 1 were vented to the REDC hot cell. However, a simplified off-gas treatment system (Figure 6) was used during voloxidation batches in the stainless steel rectangular reactor to capture tritium (as water), ${ }^{14} \mathrm{C}$ (as carbon dioxide), I (as elemental iodine), and other volatilized fission products from the reactor off-gas, prior to discharge to the REDC off-gas treatment system. 


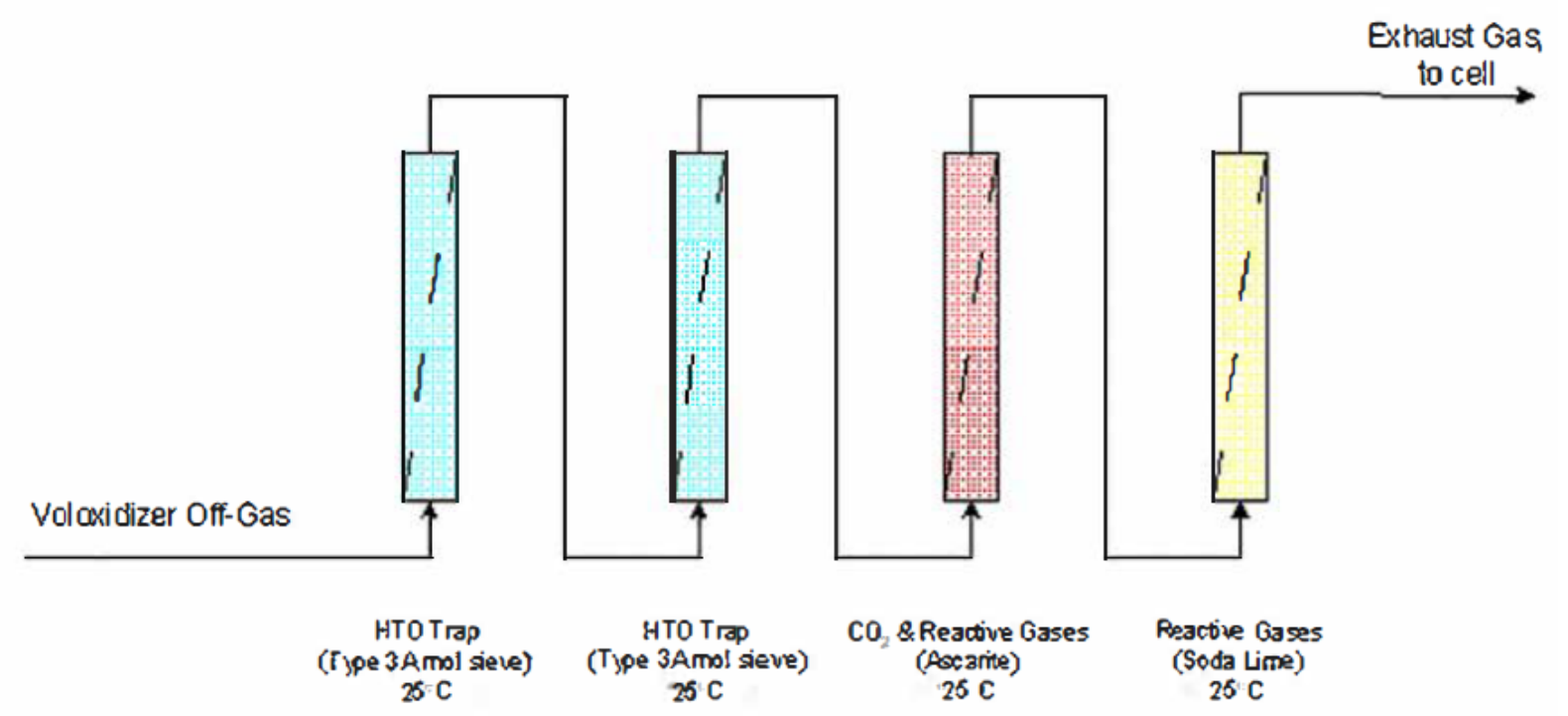

Figure 6. Simplified off-gas trapping system for tests with Dresden-1 fuel.

The first two columns were packed with type- $3 \AA$ molecular sieve to capture tritiated water. The intention was that any tritium on the secondary column would provide clues to the width of the sorption front. Carbon dioxide (containing ${ }^{14} \mathrm{C}$ ) and iodine $\left({ }^{129} \mathrm{I}\right)$ were to be captured on the third column containing Ascarite ${ }^{\circledR}$ (sodium hydroxide-coated silica). Capture of $\mathrm{CO}_{2}$ and $\mathrm{I}_{2}$ occurs through a chemical reaction that forms sodium carbonate and sodium iodide, respectively.

As a backup to the $\mathrm{CO}_{2}$ trap, a soda-lime column (a mixture of calcium hydroxide [70-80\%], water [10$20 \%$ ], sodium hydroxide [1-4\%], and potassium hydroxide $[0-4 \%])$ was used to trap $\mathrm{I}_{2}, \mathrm{CO}_{2}\left({ }^{14} \mathrm{C}\right)$ and any of the other possible trace level emissions (e.g., $\mathrm{Tc}_{2} \mathrm{O}_{7}$ and $\mathrm{SeO}_{2}$ ). It was anticipated that metal-based semivolatiles (e.g., Cs-containing species) would plate out on the metal exhaust lines of the voloxidizer or condense as finely divided particulates as the gas stream cooled. If the latter occurred, the particulates would collect in the packed columns on the packing material. The four columns were connected in series with flexible tubing.

To minimize loading of the off-gas traps with water and $\mathrm{CO}_{2}$, a precolumn containing Drierite (anhydrous calcium sulfate) and type $5 \AA$ molecular sieve (mean zeolite composition of $0.7 \mathrm{CaO}, 0.3 \mathrm{Na}_{2} \mathrm{O}, \mathrm{Al}_{2} \mathrm{O}_{3}$, $2 \mathrm{SiO}_{2} \cdot \mathrm{nH}_{2} \mathrm{O}$ ) was connected between the air supply and the voloxidizer unit. The traps were removed from the hot cell after processing and were transferred to the analytical laboratories for analysis. The trapping material was removed from the columns and placed in secondary containers for measurement of changes in sorbent mass. Gamma scans were used as a coarse measurement of radioactive materials capture. The analysis technique was liquid scintillation counting, preceded by leaching of the solid trapping material and distillation to obtain a clean analyte.

The data shown in Table 3 indicated a mass increase (except for trap \#4, where some material may have been lost during transfer) of the traps. The increase was mostly attributed to moisture and carbon dioxide in the air fed to the voloxidizer. Most of the tritium (H-3) was captured on the first trap as expected. However, the quantity of tritium captured was only $1 \%$ of that expected, based on the age and burnup of the fuel. However, this fuel had been sheared many years before, and the tritium may have slowly diffused out of the fuel segments during storage. 
Table 3. Summary of analysis of Campaign 1 voloxidation off-gas traps.

\begin{tabular}{|c|c|c|c|c|c|}
\hline \multirow{2}{*}{ Trap no. } & \multirow{2}{*}{$\begin{array}{c}\text { Initial sorbent mass } \\
(\mathbf{g})\end{array}$} & $\begin{array}{c}\text { Mass increase } \\
(\mathbf{g})\end{array}$ & \multicolumn{3}{|c|}{ Total collected } \\
\cline { 3 - 6 } & & & $\mathbf{B q})$ & $\mathbf{3}$ \\
\hline 1 & 19.91 & 0.9704 & $7.8 \mathrm{E}+7$ & $<2.8 \mathrm{E}+3$ & $1.6 \mathrm{E}+3$ \\
\hline 2 & 19.61 & 0.2412 & $<1.7 \mathrm{E}+4$ & $<9.9 \mathrm{E}+3$ & $4.0 \mathrm{E}+1$ \\
\hline 3 & 26.74 & 0.6712 & - & $<1.3 \mathrm{E}+3$ & $<3.6 \mathrm{E}+1$ \\
\hline 4 & 18.87 & -0.9987 & $1.4 \mathrm{E}+2$ & $<8.9 \mathrm{E}+3$ & $<8.3 \mathrm{E}+0$ \\
\hline
\end{tabular}

A small amount of iodine was expected to be trapped on the molecular sieve (first two columns), and the bulk was to be captured on the Ascarite ${ }^{\circledR}$ (column 3). However, most of the ${ }^{129} \mathrm{I}(0.042 \mu \mathrm{Ci}$ ) was trapped on the molecular sieve, likely because of the low mass of iodine. The ${ }^{14} \mathrm{CO}_{2}$ was expected to trap almost exclusively on the Ascarite ${ }^{\mathbb{R}}$. Difficulties with the analysis of ${ }^{14} \mathrm{C}$ prevented the formulation of conclusive results. An improved method and apparatus for analysis of ${ }^{14} \mathrm{C}$-containing samples was identified as a need for future experiments.

For Campaign 2 in the IFEL hot cell, a stainless steel equipment rack containing a $3 \AA$ molecular sieve for tritium trapping, a silver zeolite (AgZ) trap for iodine, a solid sorbent-based system for $\mathrm{Xe} / \mathrm{Kr}$ capture, and a caustic scrubber for ${ }^{14} \mathrm{C}$, was placed in the adjoining, out-of-cell transfer area, and connected via piping through a HEPA filter to the in-cell voloxidation reactor. A description of this equipment and results obtained is described in a separate report [Ref. 7].

\section{FUEL DISSOLUTION}

\subsection{EQUIPMENT}

The existing fuel dissolver tank in the REDC hot cell was designed, fabricated, installed, and used in earlier R\&D experiments for dissolving fuel from sheared fuel rod segments was used in the CETE campaigns. The dissolver tank is mounted on a modular rack with assessory equipment, as shown in Figure 7. It is constructed of stainless steel with a volumetric capacity of $14 \mathrm{~L}$ and a batch size of $2 \mathrm{~kg}$ of UNF. The dissolver tank has an external water jacket that can be used to either cool or heat the tank. Airsparging is used to mix the dissolver solution and oxide particles. A removable basket made of stainless steel screen is available to hold clad fuel pieces, but the basket was not used for the powder dissolutions of the CETE campaigns. 


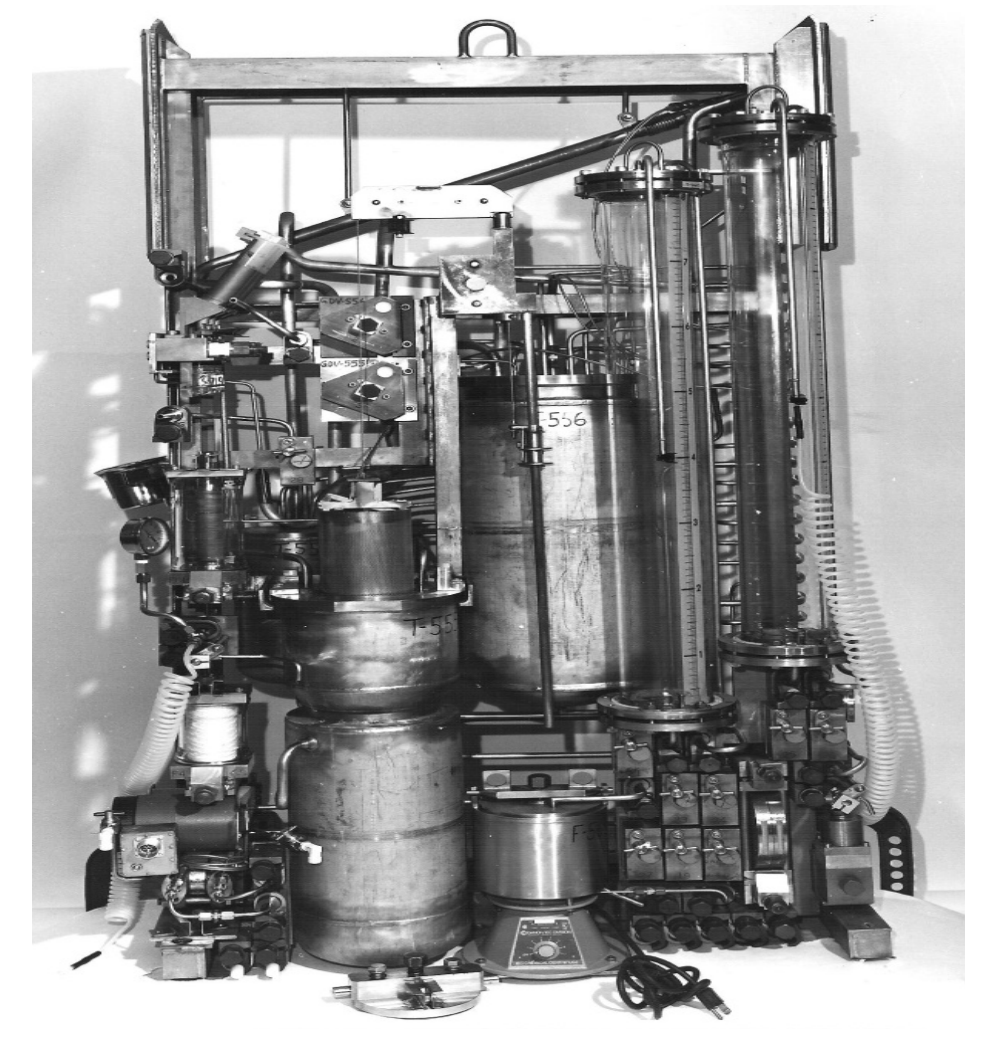

Figure 7. Picture of the rack containing the dissolution equipment.

Before CETE Campaign 2, a vertical powder feed hopper and horizontal, rotatable, segment-transfer cylinder (Figure 8) was designed, fabricated, and installed in the lid position of the dissolver tank to alleviate the problems (described below in Section 4.2) which were encountered during Campaign 1 dissolutions.

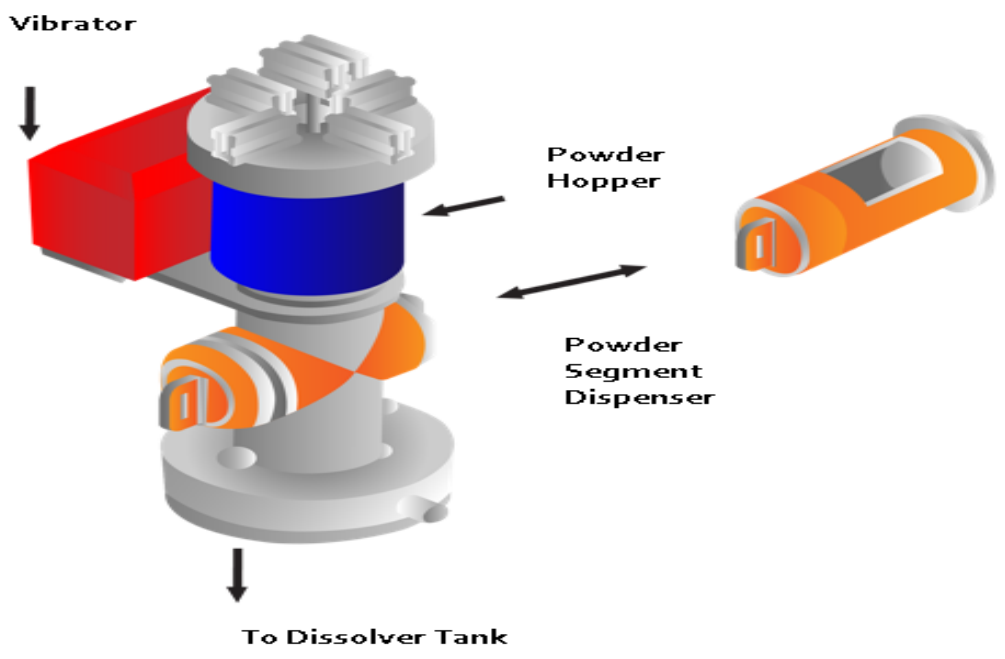

Figure 8. Powder feeder diagram.

When the horizontal segment-transfer cylinder was rotated open to the hopper, the segment chamber was loaded with fuel powder, and when the cylinder was turned $180^{\circ}$, the fuel powder segment in the transfer 
chamber was emptied into the dissolver tank. Seals in the rotated cylinder segment-feeder kept acidic vapors from the dissolver tank from rising into the hopper. This equipment enabled small segments of the powder to be fed into the dissolver in discrete increments of $\sim 150-200 \mathrm{~g}$, which enabled a controlled dissolution

\subsection{DISSOLUTION PROCEDURES}

In CETE Campaign 1, two sequential $\sim 1.8 \mathrm{~kg}$ batches of voloxidized Dresden-1 used fuel powder were dissolved in nitric acid $\left(\mathrm{HNO}_{3}\right)$. In the first batch, some of the acid was added initially to the empty dissolver, and then the powder was added while sparging the solution with air. This technique allowed some fission gases and $\mathrm{NO}_{\mathrm{x}}$ fumes to escape into the hot cell before the dissolver lid could be reinstalled. Therefore, in the second batch, the powder was added to the empty tank, the lid was installed, and acid was then added via the existing solution addition line from the chemical reagent makeup area above the hot cell. This technique was not free of problems either, and some plugging of the deep instrument probes in the tank occurred before the $\mathrm{HNO}_{3}$ finally dissolved the oxide out of the probes. Even with these problems, the fuel dissolution was completed successfully. The dissolved component solutions were combined, analyzed, filtered to remove undissolved solids (UDS), and adjusted to feed conditions for the UREX co-decontamination solvent extraction process step.

In CETE Campaign 2, two sequential batches of voloxidized, high-burnup, 5 year decayed North Anna PWR UNF powder were dissolved. The first batch had been voloxidized in air at $600^{\circ} \mathrm{C}$, and the second batch had been voloxidized in oxygen at $600^{\circ} \mathrm{C}$. Hulls were mechanically removed from the fuel powder before dissolution. In each batch, $8 \mathrm{MHNO}_{3}$ was transferred into the dissolver and then heated to $40^{\circ} \mathrm{C}$ before powder introduction.

In the first batch dissolution, $\sim 420 \mathrm{~g}$ of the fuel powder was spilled during the first attempt to load powder into the hopper and was diverted to rework accumulation. The remaining $760 \mathrm{~g}$ of fuel powder was dissolved during the first batch dissolution, and another 1,160 $\mathrm{g}$ was dissolved during the second batch. The powder addition increments were spread over a total of 30 min during the first batch and 60 min during the second batch. After completion of the powder addition in both batches, the hopper was flushed into the dissolver tank, which was then was heated to $90{ }^{\circ} \mathrm{C}$ and held for 8 hours to complete the dissolution.

\subsection{DISSOLUTION RESULTS AND COMPARISONS}

Analyses of the combined CETE Campaign 2 batch dissolutions are shown in Table 4 with those from Campaign 1. Unfortunately, only limited mass analyses were obtained for the Campaign 2 solution; thus, element measurements and comparisons were made on the basis of activity analyses. Compared to ORIGEN calculations, most of the component analyses in the dissolved solution from each campaign agreed well with ORIGEN calculations. Three noble metal fission products, $\mathrm{Ru}, \mathrm{Pd}$, and Tc, were exceptions in which significant portions were found in the UDS (see discussion and data in Section 4.4). In addition, the $\mathrm{Ru}$ species, $\mathrm{RuO}_{4}$, is volatile and can be released into the dissolver off-gas. 
Table 4. Comparison of measured dissolver solution components with ORIGEN predictions.

\begin{tabular}{|c|c|c|c|c|}
\hline & \multicolumn{2}{|c|}{$\begin{array}{c}\text { CETE Campaign 1 } \\
\text { Dresden-1 BWR UNF } \\
24 \text { GWd/MT burnup } \\
32 \text { y decay }\end{array}$} & \multicolumn{2}{|c|}{$\begin{array}{c}\text { CETE Campaign } 2 \\
\text { North Anna PWR } \\
\sim 65 \text { GWd/MT burnup } \\
5 \text { y decay }\end{array}$} \\
\hline & $\begin{array}{c}\text { ORIGEN } \\
\text { prediction }\end{array}$ & $\begin{array}{l}\text { Dissolved } \\
\text { solution }\end{array}$ & $\begin{array}{c}\text { ORIGEN } \\
\text { prediction }\end{array}$ & $\begin{array}{c}\text { Dissolved } \\
\text { solution }\end{array}$ \\
\hline $\mathrm{U}$ & $3,082 \mathrm{~g}$ & $2,950 \mathrm{~g}$ & $1,508 \mathrm{~g}$ & $1,652 \mathrm{~g}$ \\
\hline $\mathrm{Pu}$ & $19.5 \mathrm{~g}$ & $20.45 \mathrm{~g}$ & $21.6 \mathrm{~g}$ & $24.5 \mathrm{~g}$ \\
\hline $\mathrm{Np}$ & $0.74 \mathrm{~g}$ & $0.89 \mathrm{~g}$ & $1.56 \mathrm{~g}$ & $1.65 \mathrm{~g}$ \\
\hline $\mathrm{Am}$ & $2.0 \mathrm{~g}$ & $2.27 \mathrm{~g}$ & $1.58 \mathrm{~g}$ & $1.78 \mathrm{~g}$ \\
\hline $\mathrm{Cm}-244$ & $\underline{0.008 \mathrm{~g}}$ & $\underline{0.031 \mathrm{~g}}$ & $\underline{0.47 \mathrm{~g}}$ & $\underline{0.52 \mathrm{~g}}$ \\
\hline $\begin{array}{c}\text { Total } \\
\text { Actinides }\end{array}$ & $3,104.2 \mathrm{~g}$ & $2,973.6 \mathrm{~g}$ & $1,533.2 \mathrm{~g}$ & $1,680.5 \mathrm{~g}$ \\
\hline $\mathrm{Y}$ & $1.03 \mathrm{~g}$ & $1.02 \mathrm{~g}$ & $1.33 \mathrm{~g}$ & \\
\hline $\mathrm{Zr}$ & $8.6 \mathrm{~g}$ & $7.45 \mathrm{~g}$ & $11.1 \mathrm{~g}$ & \\
\hline Mo & $7.5 \mathrm{~g}$ & $6.68 \mathrm{~g}$ & $10.9 \mathrm{~g}$ & \\
\hline Tc & $1.9 \mathrm{~g}$ & $1.12 \mathrm{~g}$ & $2.3 \mathrm{~g}$ & $0.122 \mathrm{~g}$ \\
\hline $\mathrm{Ru}$ & $4.8 \mathrm{~g}$ & $0.49 \mathrm{~g}$ & $9.3 \mathrm{~g}$ & \\
\hline $\mathrm{Ru}-106$ & & & $40 \mathrm{Ci}$ & $2.3 \mathrm{Ci}$ \\
\hline $\mathrm{Pd}$ & $2.8 \mathrm{~g}$ & $0.009 \mathrm{~g}$ & $5.0 \mathrm{~g}$ & \\
\hline $\mathrm{La}$ & $2.7 \mathrm{~g}$ & $3.04 \mathrm{~g}$ & $3.9 \mathrm{~g}$ & \\
\hline $\mathrm{Ce}$ & $5.2 \mathrm{~g}$ & $5.72 \mathrm{~g}$ & $7.7 \mathrm{~g}$ & \\
\hline Ce-144 & & & $17.6 \mathrm{Ci}$ & $13.6 \mathrm{Ci}$ \\
\hline $\operatorname{Pr}$ & $2.5 \mathrm{~g}$ & $2.75 \mathrm{~g}$ & $3.6 \mathrm{~g}$ & \\
\hline $\mathrm{Nd}$ & $9.0 \mathrm{~g}$ & $9.98 \mathrm{~g}$ & $11.7 \mathrm{~g}$ & \\
\hline $\mathrm{Sm}$ & $2.0 \mathrm{~g}$ & $1.74 \mathrm{~g}$ & $2.5 \mathrm{~g}$ & \\
\hline $\mathrm{Eu}$ & $0.24 \mathrm{~g}$ & $0.29 \mathrm{~g}$ & $0.49 \mathrm{~g}$ & \\
\hline Eu-154 & & $0.935 \mathrm{Ci}$ & $17.1 \mathrm{Ci}$ & $15.0 \mathrm{Ci}$ \\
\hline $\mathrm{Gd}$ & $0.21 \mathrm{~g}$ & $0.36 \mathrm{~g}$ & $0.71 \mathrm{~g}$ & \\
\hline Cs & $4.3 \mathrm{~g}$ & $4.52 \mathrm{~g}$ & $8.2 \mathrm{~g}$ & \\
\hline Cs-134 & & & $110 \mathrm{Ci}$ & $105 \mathrm{Ci}$ \\
\hline Cs-137 & & $110 \mathrm{Ci}$ & $303 \mathrm{Ci}$ & $321 \mathrm{Ci}$ \\
\hline $\mathrm{Ba}$ & $4.6 \mathrm{~g}$ & $5.1 \mathrm{~g}$ & $5.7 \mathrm{~g}$ & \\
\hline $\mathrm{Rb}$ & $0.82 \mathrm{~g}$ & $0.23 \mathrm{~g}$ & $1.05 \mathrm{~g}$ & \\
\hline $\mathrm{Sr}$ & $1.37 \mathrm{~g}$ & $1.43 \mathrm{~g}$ & $2.4 \mathrm{~g}$ & \\
\hline Sr-90 & & $61 \mathrm{Ci}$ & $189 \mathrm{Ci}$ & $292 \mathrm{Ci}$ \\
\hline
\end{tabular}

\subsection{UNDISSOLVED SOLIDS (UDS)}

The UDS weight and composition were not obtained after CETE Campaign 1 dissolutions but were obtained subsequently in small-scale R\&D dissolutions of voloxidized Dresden-1 used fuel. At the end of each dissolution batch of Campaign 2, the solution was filtered through three filter papers with different porosity ratings $(22,8$, and $2.7 \mu \mathrm{m})$ to collect the UDS for weighing and shipment to Savannah River 
National Laboratory (SRNL) for component analyses and use in waste form studies [Ref. 8]. Comparisons of the measurements and estimates from each campaign are shown in Table 5.

Table 5. UDS measurements and estimates.

\begin{tabular}{|c|c|c|c|c|}
\hline & \multicolumn{2}{|c|}{$\begin{array}{c}\text { CETE Campaign } 1 \\
\text { Dresden-1 BWR UNF } \\
24 \text { GWd/MT burnup } \\
32 \text { y decay }\end{array}$} & \multicolumn{2}{|c|}{$\begin{array}{c}\text { CETE Campaign } 2 \\
\text { North Anna PWR } \\
\sim 65 \text { GWd/MT burnup } \\
5 \text { y decay }\end{array}$} \\
\hline & $\begin{array}{c}\text { wt.\% of } \\
\text { fuel oxide }^{(a)}\end{array}$ & $\begin{array}{c}\text { wt.\% } \\
\text { of UDS } \\
\end{array}$ & $\begin{array}{c}\text { wt.\% of } \\
\text { fuel oxide }^{(b)}\end{array}$ & $\begin{array}{c}\text { wt.\% } \\
\text { of UDS }^{(\mathfrak{c})}\end{array}$ \\
\hline $\mathrm{U}$ & 14 & & 7 to 26 & \\
\hline $\mathrm{Pu}$ & 0.2 & & 1.1 to 1.3 & \\
\hline $\mathrm{Np}$ & 0.04 & & Not Meas. & \\
\hline $\mathrm{Am}$ & Not Meas. & & 0.06 to 0.2 & \\
\hline $\mathrm{Cm}-244$ & Not Meas. & & 0.02 & \\
\hline $\mathrm{Zr}$ & & 4 & & 14 to 25 \\
\hline Mo & & 19 & & 13 to 23 \\
\hline $\mathrm{Tc}$ & & 11 & & 1 to 2 \\
\hline $\mathrm{Ru}$ & & 20 & & 20 to 34 \\
\hline $\mathrm{Pd}$ & & 27 & & 9 to 19 \\
\hline Other & $\underline{\mathrm{d}}$ & Not Meas. & & 2 to 4 \\
\hline Total & 0.35 & & 1.02 & \\
\hline
\end{tabular}

\footnotetext{
(a) Estimated from UDS solubility measurements

(b) Weight measured at ORNL

(c) Estimated from SRNL analyses

(d) Other, such as $\mathrm{Fe}, \mathrm{Cr}, \mathrm{Ni}, \mathrm{Si}$, etc.
}

The total UDS and Pu content weight percentages obtained in CETE Campaigns 1 and 2 are listed along with previous measurements [Ref. 9] in Table 6. The data in Table 6 compare well with previous measurements for total UDS and show how the amount of UDS increases with fuel burnup. However, the Insoluble $\mathrm{Pu}$ data in the CETE campaigns were lower than in previous measurements. 
Table 6. Comparison of UDS vs burnup from the $\mathrm{HNO}_{3}$ dissolution of used LWR oxide fuels ${ }^{(a)}$.

\begin{tabular}{|l|r|r|r|r|r|}
\hline & Dresden-3 & \multicolumn{1}{|c|}{ Oconnee-1 } & \multicolumn{1}{c|}{ Dresden-1 } & \multicolumn{1}{c|}{ Robinson-2 } & \multicolumn{1}{c|}{ North Anna } \\
\hline Reactor burnup, MWd/t & 18,000 & 23,000 & 24,000 & 31,000 & $\sim 65,000$ \\
\hline Total UDS & & & & & \\
\hline Oxidized, wt.\% used fuel & 0.280 & 0.370 & 0.35 & 0.590 & 1.02 \\
\hline Not oxidized, wt.\% used fuel & 0.026 & 0.175 & & 0.200 & \\
\hline Insoluble Pu & & & & & \\
\hline Oxidized, \% used fuel & 0.025 & 0.024 & $<0.001$ & 0.019 & $0.011-0.013$ \\
\hline Not oxidized, \% of used fuel & 0.016 & 0.049 & & 0.004 & \\
\hline
\end{tabular}

(a) CETE Campaign data in blue type

Other points of interest are listed here:

1. The UDS data for Dresden-1 used fuel were calculated from UDS solubility measurements on a used fuel sample that had been voloxidized with $\mathrm{NO}_{2}$ at $\sim 325^{\circ} \mathrm{C}$. Thus, the amount of $\mathrm{Pu}$ contained in the UDS was lower, possibly because of the lower voloxidation temperature.

2. Table 7 shows an informative comparison of the mass distribution of noble metal and actinide elements in the used fuels between those in the dissolved solution and the UDS, calculated as a percentage of the expected amounts predicted by ORIGEN modeling. The data were calculated from the information shown in Tables 4 and 5.

3. For the higher burnup, shorter decayed North Anna used fuel processed in CETE Campaign 2, the UDS elemental concentration analyses were made at SRNL on three of six samples of the UDS, so it was not possible to calculate an average concentration for the entire UDS. Thus, the range of concentrations that were measured were used in Table 7.

4. For each element of the Dresden-1 used fuel, other than $\mathrm{Ru}$, the sum of the dissolved solution and UDS accounted for more than $100 \%$ of the element predicted by ORIGEN. The sum for Ru was 54\%, implying likely loss to volatility of $\mathrm{RuO}_{4}$.

5. The $\mathrm{U}$ and Pu elements in the Dresden-1 used fuel, and likely other actinides, were essentially all dissolved in $\mathrm{HNO}_{3}$, whereas the Pd element was essentially all in the UDS. The other noble metal elements had significant concentrations in both the dissolved solution and UDS. The data for the North Anna used fuel appears similar but is more difficult to discern because of the range of concentrations in the UDS for this fuel.

6. Inductively coupled plasma mass spectrometry analyses for Tc in the dissolved solution varied widely (from 54\% in the Dresden-1 used fuel to 5\% in the North Anna used fuel), perhaps because of the higher burnup of the fuel. 
Table 7. Distribution of noble metals and actinide elements between dissolver solutions and UDS. ${ }^{\text {(a) }}$

\begin{tabular}{|c|c|c|c|c|c|c|}
\hline \multicolumn{4}{|c|}{$\begin{array}{c}\text { CETE Campaign } 1 \\
\text { Dresden-1 BWR UNF } \\
24 \text { GWd/MT Burnup } \\
32 \text { y decay }\end{array}$} & \multicolumn{3}{|c|}{$\begin{array}{c}\text { CETE Campaign } 2 \\
\text { North Anna PWR UNF } \\
\sim 65 \text { GWd/MT Burnup } \\
5 \text { y decay }\end{array}$} \\
\hline & $\begin{array}{c}\text { Dissolver } \\
\text { Solution } \\
(\%)\end{array}$ & $\begin{array}{c}\mathbf{U D S}^{(\mathbf{b})} \\
(\mathbf{\%})\end{array}$ & $\begin{array}{c}\text { Total } \\
(\%)\end{array}$ & $\begin{array}{c}\text { Dissolver } \\
\text { Solution } \\
(\%)\end{array}$ & $\begin{array}{c}\mathbf{U D S}^{(\mathbf{c})} \\
(\%)\end{array}$ & $\begin{array}{c}\text { Total } \\
(\%)\end{array}$ \\
\hline $\mathrm{Zr}$ & 87 & 5 & 92 & Not Measured & $25-45$ & - \\
\hline Mo & 89 & 27 & 116 & Not Measured & $24-42$ & - \\
\hline $\mathrm{Tc}$ & 54 & 61 & 120 & 5 & $9-17$ & $14-22$ \\
\hline $\mathrm{Ru}$ & 10 & 44 & 54 & 6 & $42-72$ & $48-78$ \\
\hline $\mathrm{Pd}$ & 0.3 & 102 & 102 & Not Measured & $36-75$ & - \\
\hline $\mathrm{U}$ & 96 & 0.05 & 96 & 110 & $0.09-0.34$ & - \\
\hline $\mathrm{Pu}$ & 105 & 0.1 & 105 & 113 & $1.0-1.2$ & - \\
\hline
\end{tabular}

(a) Weight percent (wt.\%) based on ORIGEN calculation for total element

(b) Estimated from UDS solubility measurement using UDS from dissolved Dresden-1 fuel that had been previously voloxidized at $325^{\circ} \mathrm{C}$ using $\mathrm{NO}_{2}$

(c) Estimated from UDS measurements made at SRNL [Ref. 8]

\subsection{DISSOLVER OFF-GAS}

In CETE Campaign 1, the dissolver off-gas was routed through a temporary off-gas trap system in an attempt to capture ${ }^{129}$ I. During the first batch dissolution of Campaign 1 the system used activated charcoal in the two beds. The rapid dissolution of the fuel that occurred during the direct addition to the hot $\mathrm{HNO}_{3}$ and the subsequent release of $\mathrm{NO}_{\mathrm{x}}$ into off-gas train adversely affected the trapping ability of the charcoal. For the second batch dissolution, the charcoal was replaced with silver-exchanged mordenite (AgZ). After each dissolution batch, the beds were taken from the hot cell and the contents removed for analysis. The results are shown in Table 8.

Table 8. Summary of analysis of dissolver off-gas traps in CETE Campaign 1.

\begin{tabular}{|l|c|c|}
\hline & Total $\left.^{\mathbf{1 2 9}} \mathbf{I} \mathbf{( B q}\right)$ & Total $^{\mathbf{1 2 9}} \mathbf{I} \mathbf{( g )}$ \\
\hline $\begin{array}{l}\text { Dissolution Batch 1 - Traps were } \\
\text { Activated Carbon }\end{array}$ & $1.4 \times 10^{5}$ & 0.0215 \\
\hline $\begin{array}{l}\text { Dissolution Batch 1 - Traps were } \\
\text { Activated Carbon }\end{array}$ & $4.7 \times 10^{5}$ & 0.0723 \\
\hline $\begin{array}{l}\text { Dissolution Batch 2 - Traps were } \\
\text { AgZ }\end{array}$ & $8.2 \times 10^{5}$ & 0.126 \\
\hline
\end{tabular}

Based on ORIGEN calculations the quantity of ${ }^{129}$ I contained in each of the $1.8 \mathrm{~kg}$ batches should have been $\sim 0.203 \mathrm{~g}$. The actual measurements amount to $46-62 \%$ of the expected iodine recovered from the off-gas system. During the Dissolution Batch 1, some of the off-gas stream was lost to the cell before the dissolver lid was installed. This loss likely accounts for the lower recovery than that obtained in Dissolution Batch 2.

For CETE Campaign 2, a stainless steel equipment rack containing a more thorough trapping system was placed in the adjoining, out-of-cell limited access area of REDC, and connected via piping through a 
HEPA filter to the in-cell dissolver off-gas header. A description of this equipment and results obtained is described in a separate report [Ref. 7].

\subsection{FRESH AND USED FUEL CLADDING COMPARISONS}

The typical elemental concentrations in Hf-free, nuclear-grade, Zr alloy-cladding, and UNF cladding are shown in Tables 9 and 10.

Table 9. Representative composition of fresh (unirradiated) $\mathrm{Zr}$ alloy-cladding.

\begin{tabular}{|c|c|c|}
\hline Element & $\begin{array}{c}\text { Zircaloy-2 } \\
\text { Used in Dresden-1 } \\
\text { Cladding } \\
\text { (ppm) }\end{array}$ & $\begin{array}{c}\text { High-Nb Zircaloy } \\
\text { Used in North Anna } \\
\text { Cladding } \\
\text { (ppm) }\end{array}$ \\
\hline $\mathrm{Sn}$ & 14,200 & $<35$ \\
\hline $\mathrm{Nb}$ & $<50$ & 10,100 \\
\hline $\mathrm{Fe}$ & 1,720 & 400 \\
\hline $\mathrm{Cr}$ & 1,020 & $<50$ \\
\hline $\mathrm{Ni}$ & 690 & $<35$ \\
\hline $\mathrm{O}$ & 1,320 & 1,370 \\
\hline $\mathrm{C}$ & 130 & 47 \\
\hline $\mathrm{N}$ & 42 & 33 \\
\hline $\mathrm{Si}$ & 91 & $<25$ \\
\hline $\mathrm{Al}$ & 45 & 41 \\
\hline $\mathrm{P}$ & $<3$ & $<3$ \\
\hline $\mathrm{S}$ & $<10$ & 21 \\
\hline $\mathrm{U}$ & $<1$ & $<1$ \\
\hline
\end{tabular}

*Samples and compositions provided by Allegheny Technologies Industries. Other high-Nb Zircloy cladding contains both $\mathrm{Nb}$ and $\mathrm{Sn}$. Balance of each type is $\mathrm{Zr}$.

Table 10. Typical radioactive component concentrations in UNF cladding.

\begin{tabular}{|l|c|c|c|}
\hline \multicolumn{1}{|c|}{ Cladding type } & $\begin{array}{c}\text { French PWRNot } \\
\text { specified }\end{array}$ & $\begin{array}{c}\text { Dresden-1 BWR } \\
\text { Zircaloy-2 }^{(\mathbf{b})}\end{array}$ & $\begin{array}{c}\text { North Anna PWR } \\
\text { High-Nb }^{(\mathbf{b})}\end{array}$ \\
\hline Burnup & $36 \mathrm{GWd} / \mathrm{MT}$ & $24 \mathrm{GWd} / \mathrm{MT}$ & $63-70 \mathrm{GWd} / \mathrm{MT}$ \\
\hline Decay time & $5 \mathrm{y}$ & $38 \mathrm{y}$ & $13 \mathrm{y}$ \\
\hline $\mathrm{U}(\mu \mathrm{g} / \mathrm{g} \mathrm{Zr})$ & 77 & - & $610^{\mathrm{c}}$ \\
\hline $\mathrm{Pu}(\mu \mathrm{g} / \mathrm{g} \mathrm{Zr})$ & 3.3 & 0.77 & $34^{\mathrm{c}}$ \\
\hline${ }^{244} \mathrm{Cm}(\mathrm{Bq} / \mathrm{g} \mathrm{Zr})$ & $3.7 \mathrm{E}+4$ & $4.2 \mathrm{E}+4$ & $1.1 \mathrm{E}+6$ \\
\hline${ }^{241} \mathrm{Am}(\mathrm{Bq} / \mathrm{g} \mathrm{Zr})$ & - & $3.9 \mathrm{E}+4$ & $2.0 \mathrm{E}+5$ \\
\hline${ }^{137} \mathrm{Cs}(\mathrm{Bq} / \mathrm{g} \mathrm{Zr})$ & $2.5 \mathrm{E}+7$ & $6.0 \mathrm{E}+6$ & $4.6 \mathrm{E}+7$ \\
\hline${ }^{125} \mathrm{Sb}(\mathrm{Bq} / \mathrm{g} \mathrm{Zr})$ & - & - & $9.6 \mathrm{E}+5$ \\
\hline${ }^{60} \mathrm{Co}(\mathrm{Bq} / \mathrm{g} \mathrm{Zr})$ & - & $3.7 \mathrm{E}+4$ & $1.8 \mathrm{E}+5$ \\
\hline${ }^{154} \mathrm{Eu}(\mathrm{Bq} / \mathrm{g} \mathrm{Zr})$ & - & $1.5 \mathrm{E}+4$ & $3.2 \mathrm{E}+5$ \\
\hline${ }^{94} \mathrm{Nb}(\mathrm{Bq} / \mathrm{g} \mathrm{Zr})$ & - & - & $1.4 \mathrm{E}+6$ \\
\hline
\end{tabular}


(a) Measured by French Alternative Energies and Atomic Energy Commission (Ref. 10).

(b) Measured by ORNL.

(c) Likely contaminated in hot cell when measured in 2016. Earlier analyses were 104 for U and 5 for Pu.

For UNF cladding, the component concentrations change with the burnup of the UNF and the decay time following discharge from the irradiation reactor ("cooling time"). Table 10 compares data published by the French Alternative Energies and Atomic Energy Commission (Ref. 10) for UNF cladding that had a burnup of $36 \mathrm{GWd} / \mathrm{MT}$ and decayed for 5 years (the typical time that UNF is reprocessed in the French reprocessing plant) with data measured at the Oak Ridge National Laboratory (ORNL) for cladding samples from the Dresden-1 BWR UNF that had a burnup of $24 \mathrm{GWd} / \mathrm{MT}$ and a decay time of 38 years (when the measurements were made) and with cladding samples from the North Anna PWR that had a burnup of 63-70 GWd/MT and a decay time of 13 years (when the measurements were made).

The radioactivity in typical UNF cladding hulls is sufficiently high to require designation as "intermediate-level waste" in Europe and "greater-than-Class C" waste in the United States, requiring relatively expensive disposal by means of emplacement into a geologic repository. Efforts made in various research programs to develop a method of decontamination of UNF cladding have been unsuccessful, primarily because the radionuclides are embedded within the cladding walls by fission product recoil. Table 10 shows that ${ }^{137} \mathrm{Cs}$ is the major radioactive source in most UNF cladding, However, during the initial decay period of $<5$ years, emissions from ${ }^{125} \mathrm{Sb}$ and other short-lived fission and activation product radionuclides are major contributors (Ref. 11). Since about 1990, most PWR UNF cladding contains a relatively high concentration of ${ }^{94} \mathrm{Nb}$ as a result of activation of the ${ }^{93} \mathrm{Nb}$ alloying agent in high- $\mathrm{Nb}$ cladding.

\section{UREX+ CO-DECONTAMINATION SOLVENT EXTRACTION}

After dissolution, the next process step in existing industrial-scale reprocessing plants is the PUREX process, a continuous, countercurrent, multistage solvent extraction that is done to co-extract $\mathrm{U}$ and $\mathrm{Pu}$, away from the fission product contaminants and minor actinides and to separate the $\mathrm{U}$ and Pu products. In both CETE campaigns, a modified PUREX process called the UREX + Co-decontamination - Partial Partitioning process was used. That process had been developed at ORNL during the previous CFRP and AFCI programs (Refs. 4,5,6).

\subsection{SOLVENT EXTRACTION EQUIPMENT IN THE ORNL REDC}

The equipment used in the solvent extraction tests for the CETE campaigns was originally installed in REDC hot cells in the late 1970s and named the Solvent Extraction Test Facility. This equipment was funded by DOE-NE for the CFRP. The solvent extraction equipment consists of three 16-stage mixersettler contactor units mounted on a modular rack (Figure 9). The contactors are made of stainless steel with a quartz window in the front that permits viewing of all settling stages. A close-up picture of a mixer-settler contactor is shown in Figure10. The top of each stage is open and thereby provides a convenient path for using small dip tubes to take solution samples or for adding reagent streams at any stage in the contactor. The volumes of the mixing and settling stages are nominally 30 and $50 \mathrm{~mL}$, respectively, and the overall flow capacity of the unit is in the $\sim 5 \mathrm{~L} / \mathrm{h}$ range. The dissolved and clarified LWR fuel solution is metered into the contactors using a metering pump and other reagents are metered from pressurized tanks from an area outside and above the hot cell. Effluent streams drain by gravity to the next lower contactor (usually the organic solvent) or to accumulation tanks in a pit below and behind the contactor cubicle. 


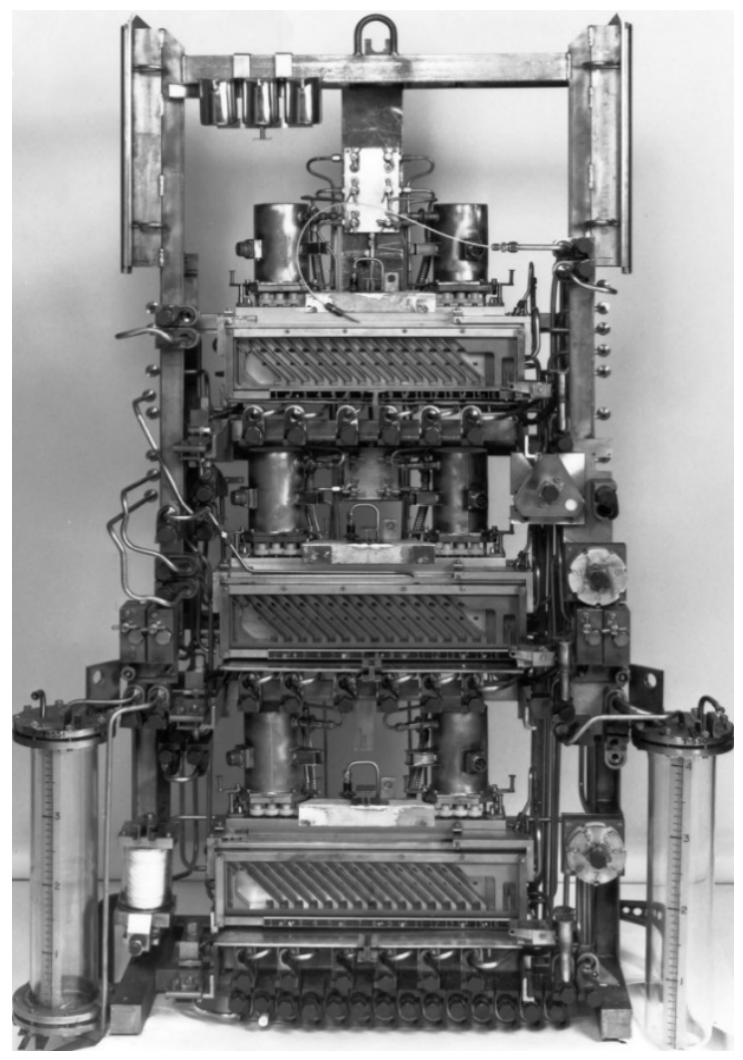

Figure 9. Mixer-settler solvent extraction rack in REDC7920.

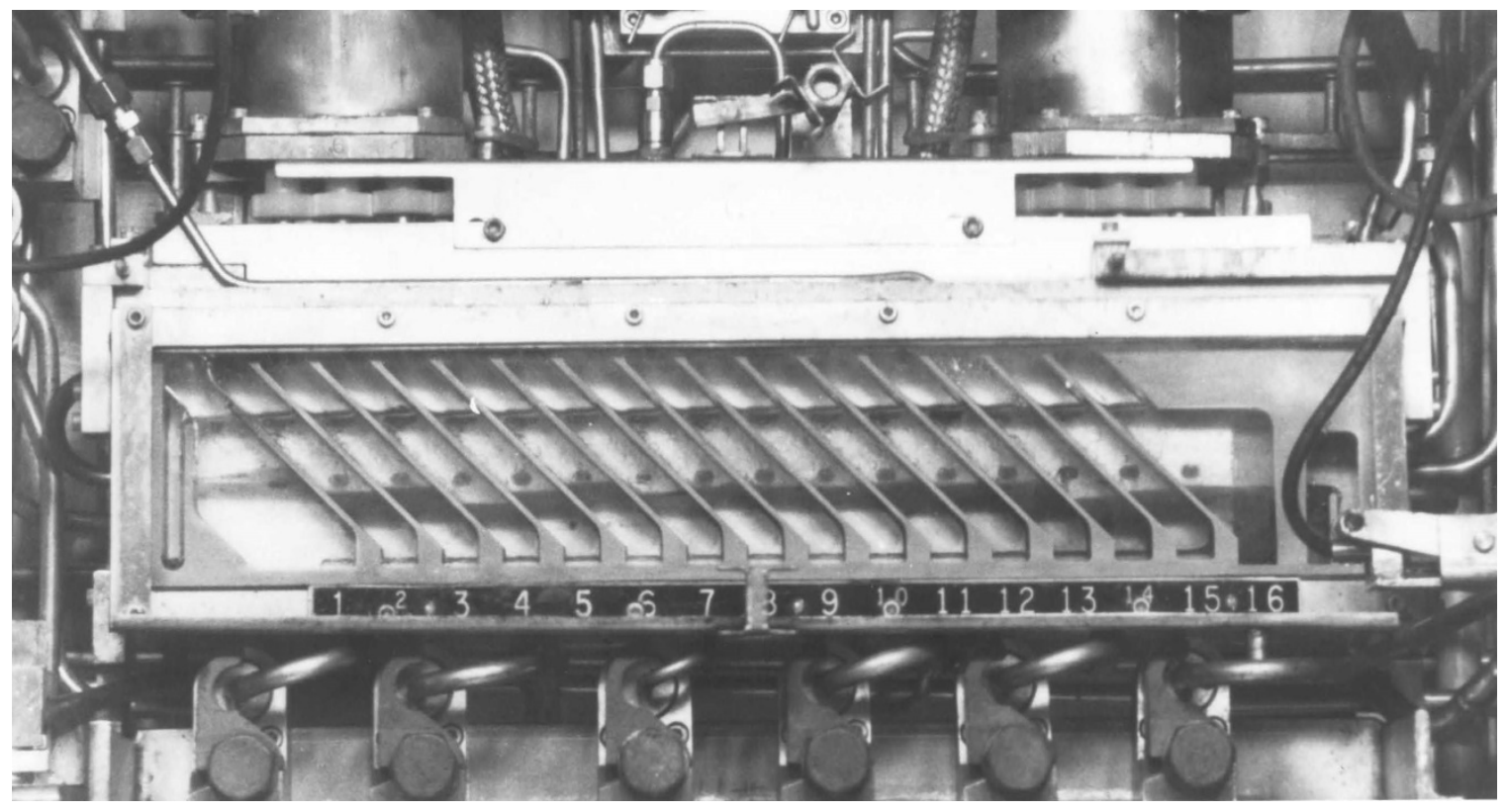

Figure 10. Close-up view of a mixer-settler in operation $6 \mathrm{~b}$ feed solution clarification.

Typically, the UDS from $\mathrm{HNO}_{3}$ dissolution of used fuels are removed from the dissolved solution components by means of centrifugation or high-efficiency filtration. Depending primarily on aging time and temperature of the conversion of the clarified dissolver solution to feed conditions for the UREX codecontamination process (i.e., feed adjustment), the soluble noble metal fission products, $\mathrm{Zr}$ and Mo, can 
form "secondary precipitates of zirconium molybdate, sometimes carrying $\mathrm{Pu}$, which can cause crud formation and accumulation at the initial organic/aqueous phase separators of the solvent extraction contactors. In early experiments of the CFRP at the ORNL REDC, various centrifuging and filtration methods were investigated. The outcome of these early experiments was the development of the deep bed filter (DBF) [Ref. 12]

This type of high efficiency DBF was used in the CETE campaigns to remove any secondary precipitates that had been formed before introduction of the feed solution to the mixer-settler contactors. The DBF was filled with diatomaceous earth in layers of coarse (Johns-Manville Celite 535), fine (Johns-Manville Hyflow Super Cel), and coarse (Johns-Manville Celite 535) that were placed over a $40 \mu \mathrm{m}$ sintered metal frit. The DBF has been a very reliable technique for preparing well clarified solvent extraction feeds from irradiated materials. Although insoluble fines will quickly blind and plug bare metal or single surface filters, the layers of diatomaceous earth in the DBF allow the particles to be dispersed and trapped before they can reach the surface of the metal frit. Because diatomaceous earth is primarily $\mathrm{SiO}_{2}$, it is also a safe inert matrix to store and dispose of the UDS and secondary precipitates.

\subsection{FLOWSHEET DESCRIPTION}

The UREX + Co-decontamination - Partial Partitioning process flowsheets used in CETE Campaigns 1 and 2 were slightly different as shown in Figures 11 and 12, respectively. The major difference was a Tc scrubbing section at high acidity added to the Campaign 2 flowsheet to try to route the Tc to the raffinate stream. This is discussed below in more detail. 


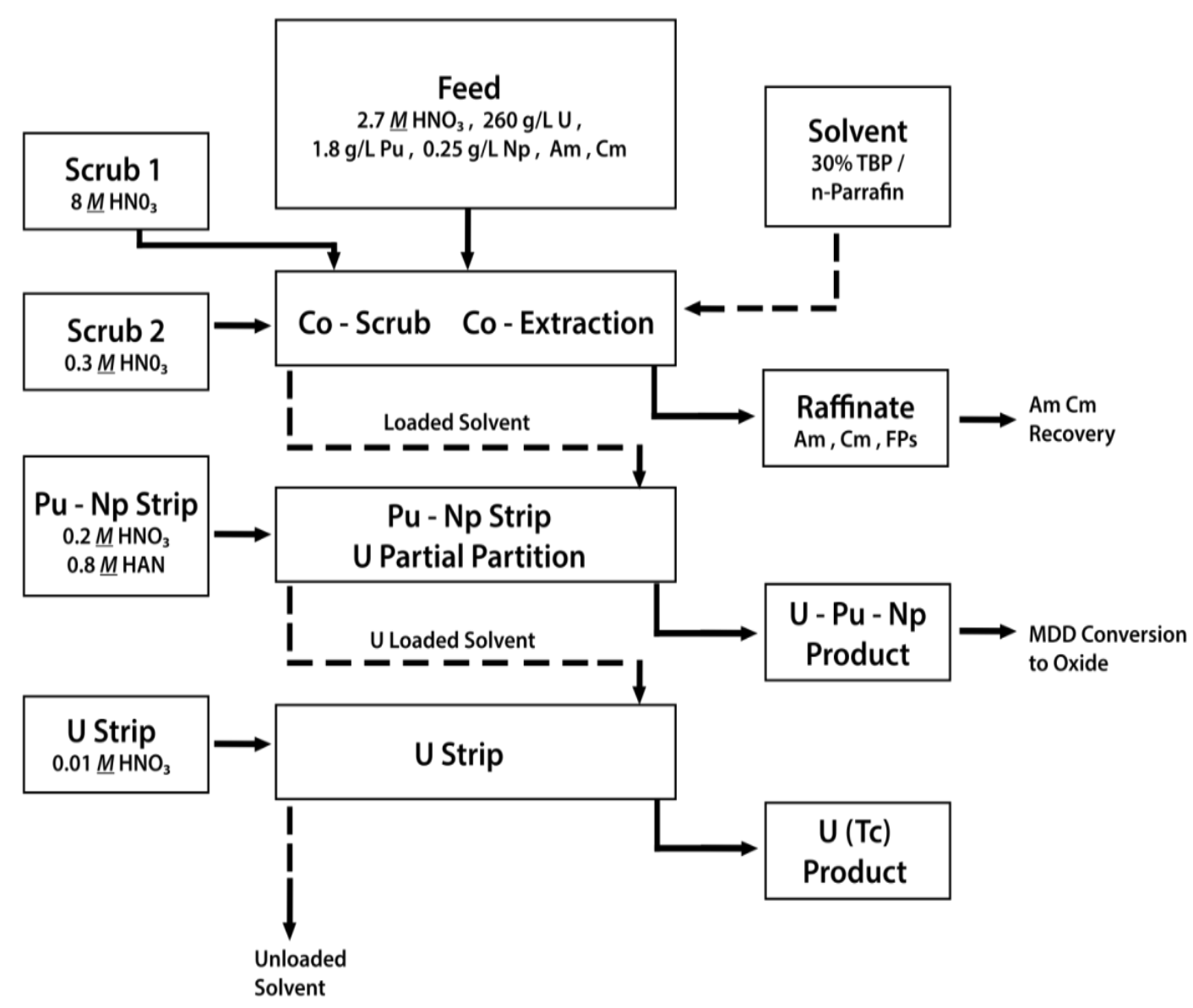

Figure 11. UREX + Co-decontamination - Partial Partitioning flowsheet used for CETE Campaign 1Dresden-1 BWR UNF (24 GWd/MT, 32 y decay).

The method of partial partitioning of the $\mathrm{U}$ component was designed to keep some of the $\mathrm{U}$ in the $\mathrm{Pu}-\mathrm{Np}$ product to provide a decrease in safeguards attractiveness level. The method was based on previous work done at both ORNL (Refs. 4,5,6) and the SRNL (Ref. 13). The goal in CETE Campaign 1 was to partition enough of the $\mathrm{U}$ into the $\mathrm{U}-\mathrm{Pu}-\mathrm{Np}$ product to produce a product containing $10-15 \% \mathrm{Pu}$, which could be downblended with more $\mathrm{U}$ to $\sim 8 \%$ to provide recycle fuel for LWRs. In CETE Campaign 2 , the goal was $\sim 30-35 \% \mathrm{Pu}$, which could be downblended to $\sim 25 \%$ to provide recycle fuel for fast reactors. 


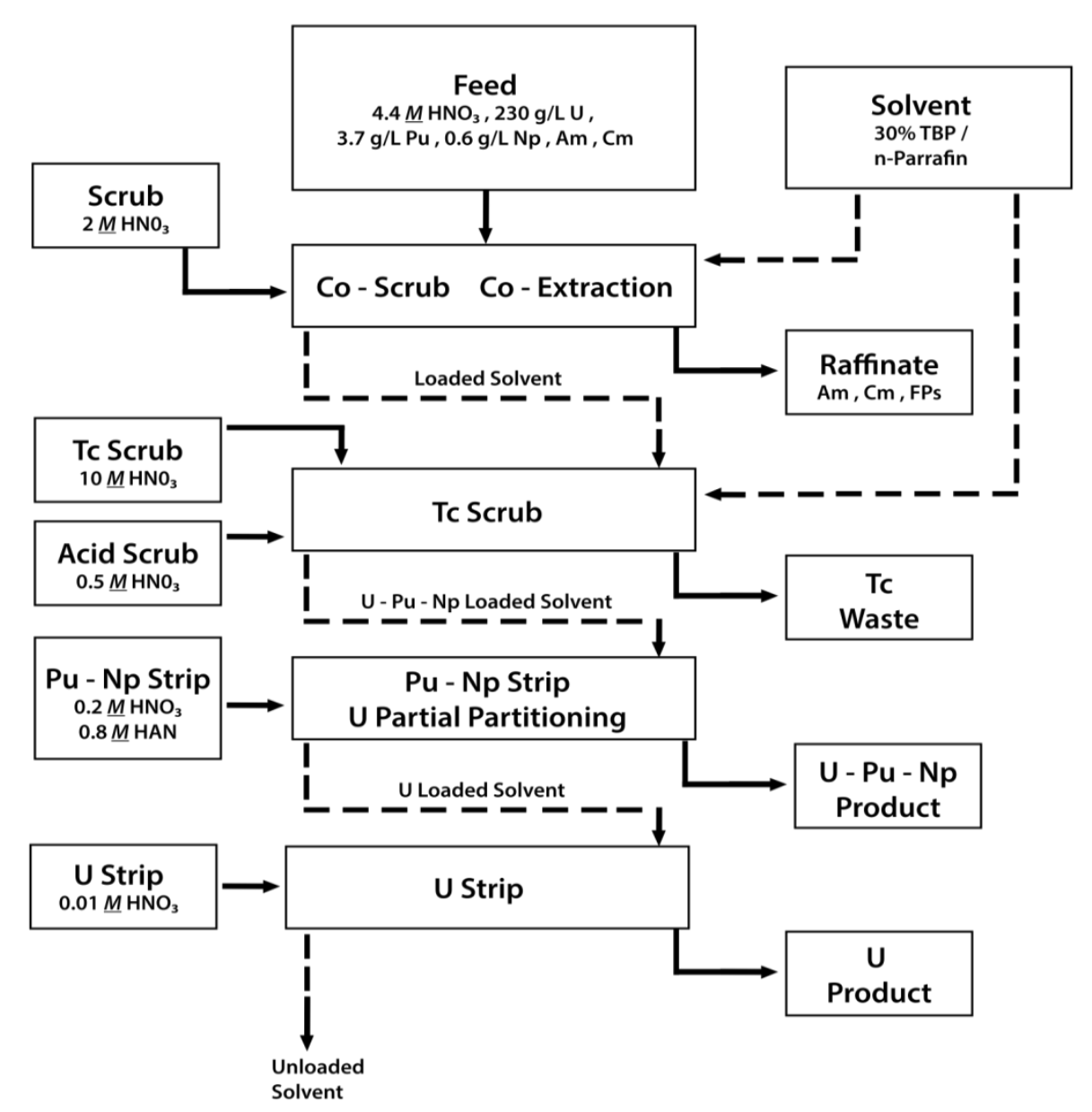

Figure 12. UREX + C0-decontamination - Partial Partitioning flowsheet used for CETE Campaign 2-North Anna PWR UNF (65 GWd/MT, 5 y decay).

\subsubsection{Co-extraction-Co-scrubbing}

Both flowsheets used tributyl- $n$-phosphate (TBP) extractant in a normal-paraffin diluent. For these process demonstrations, fresh extractant was used on a once-through basis and was not recycled. The solvent was prepurified using sodium carbonate and water scrubs and then was acidified with a dilute $\mathrm{HNO}_{3}\left(0.1 M \mathrm{HNO}_{3}\right)$ scrub before use. In the first bank of contactors, $\mathrm{U}, \mathrm{Pu}, \mathrm{Np}$, and Tc were coextracted into the solvent from the clarified feed solution and the loaded solvent was scrubbed with both low-acidity and high-acidity reagent $\mathrm{HNO}_{3}$ to remove impurities. The use of two different acid concentrations provides both low-acid and high-acid scrub sections that have been shown to improve the removal of fission products, $\mathrm{Zr}$ and $\mathrm{Ru}^{3}$, which are the most difficult to separate In CETE Campaign 2, more stages of high-acidity scrub were used to remove Tc from the loaded solvent before stripping of $\mathrm{Pu}$ and $\mathrm{Np}$. The low-acidity scrub was also used to reduce the quantity of $\mathrm{HNO}_{3}$ that is extracted in the loaded solvent before the subsequent $\mathrm{U}-\mathrm{Pu}-\mathrm{Np}$ stripping contactor bank where it would have a detrimental effect on the kinetics of the HAN reductant.

Concentration profiles (Figure 13) for $\mathrm{HNO}_{3}, \mathrm{U}, \mathrm{Pu}, \mathrm{Np}, \mathrm{Am}$, and the key fission products were obtained in CETE Campaign 1, showing the various distributions in the extraction and scrub contactor stages. Before these measurements, end stream samples were taken to show that the contactors were at steadystate operation. The profiles show refluxing of some components, especially the fission products. 

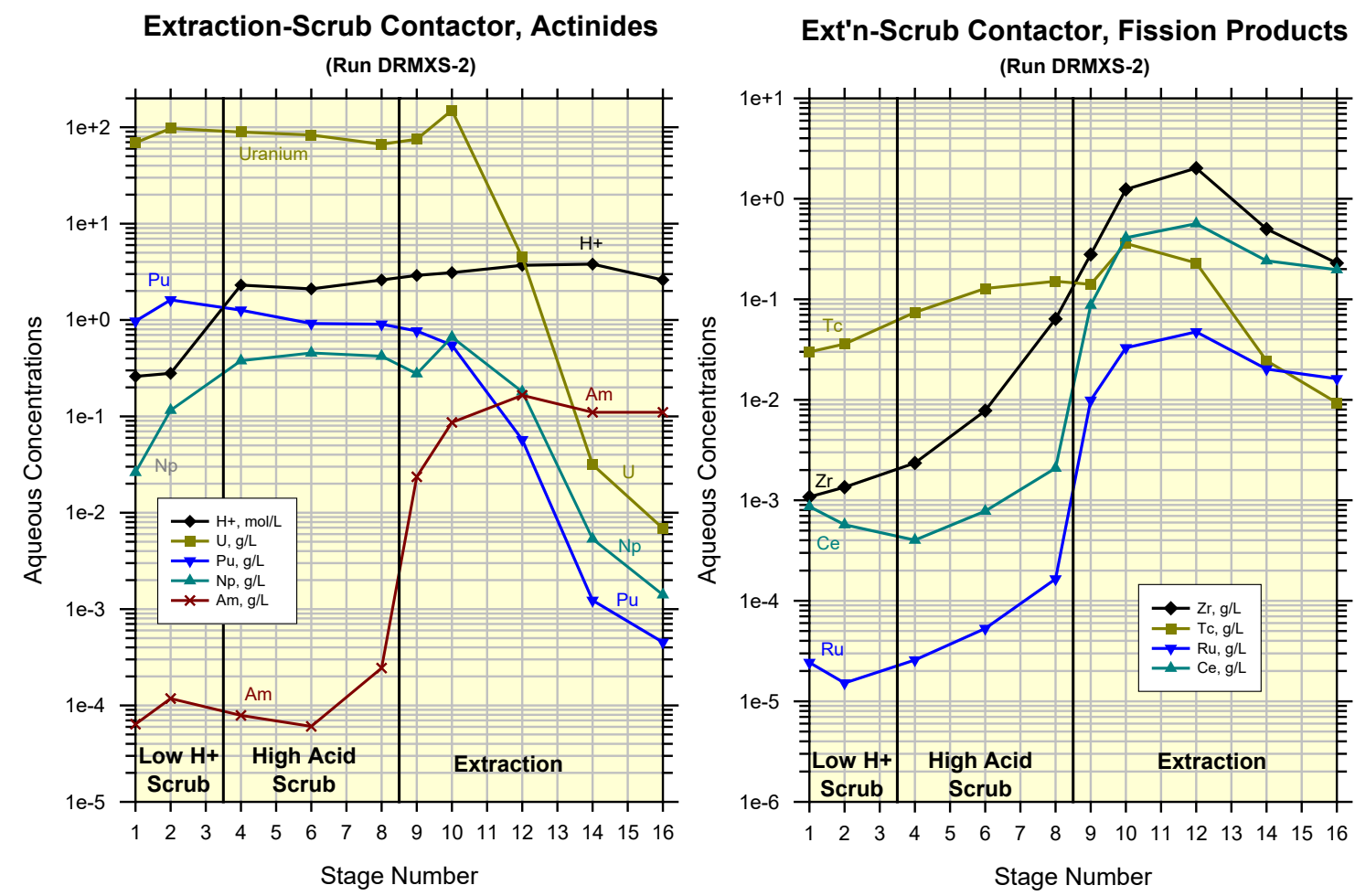

Figure 13. Measured aqueous phase concentration profiles for co-extraction-co-scrub contactor stages.

\subsubsection{Co-stripping}

The traditional PUREX process is designed to strip all the $\mathrm{Pu}$ and essentially none of the $\mathrm{U}$ in the second contactor, However, in these costrip-partial partitioning flowsheets, an SRNL-developed modification [Refs. 11, 12] was used to co-strip $\mathrm{Pu}, \mathrm{Np}$, and some of the $\mathrm{U}$ from the loaded and scrubbed organic solvent into an aqueous $\mathrm{U}-\mathrm{Pu}-\mathrm{Np}$ product solution using a chemical reductant to reduce $\mathrm{Pu}(\mathrm{IV})$ and $\mathrm{Np}(\mathrm{VI})$ to less extractable $\mathrm{Pu}(\mathrm{III})$ and $\mathrm{Np}(\mathrm{V})$. The $\mathrm{U}$ remained as extractable $\mathrm{U}(\mathrm{VI})$ but some is costripped from the solvent. An organic back-scrub of additional extractant is typically used in the traditional PUREX process to re-extract the stripped U and make a pure plutonium product. In the SRNL approach, the solvent back-scrub is omitted, and instead, the flowsheet uses excess HAN as a combination $\mathrm{Pu}-\mathrm{Np}$ reductant and an in-extractable nitrate salt to retard stripping of $\mathrm{U}$. According to computer modeling done by SRNL, the primary variables that need to be controlled to achieve the desired U/Pu ratio, are the concentration of HAN (salting agent), the aqueous to organic phase ratio (i.e., the strip flow rate), and the TBP concentration. Assuming the solvent concentration is held to $30 \%$ TBP, Figure 14 shows how the flow ratios and HAN salt concentration affect the concentration factor. The concentration factor is defined as the ratio of the percent of $\mathrm{Pu}$ in total heavy metal (HM) in the product divided by the percent of $\mathrm{Pu}$ in the feed. Assuming the Pu content in LWR fuel being reprocessed is nominally $1 \%$ of the $\mathrm{HM}$, then concentration factors of 15 and 35 were needed to make a $15 \%$ Pu product in CETE Campaign 1 a $35 \%$ Pu product in CETE Campaign 2. 


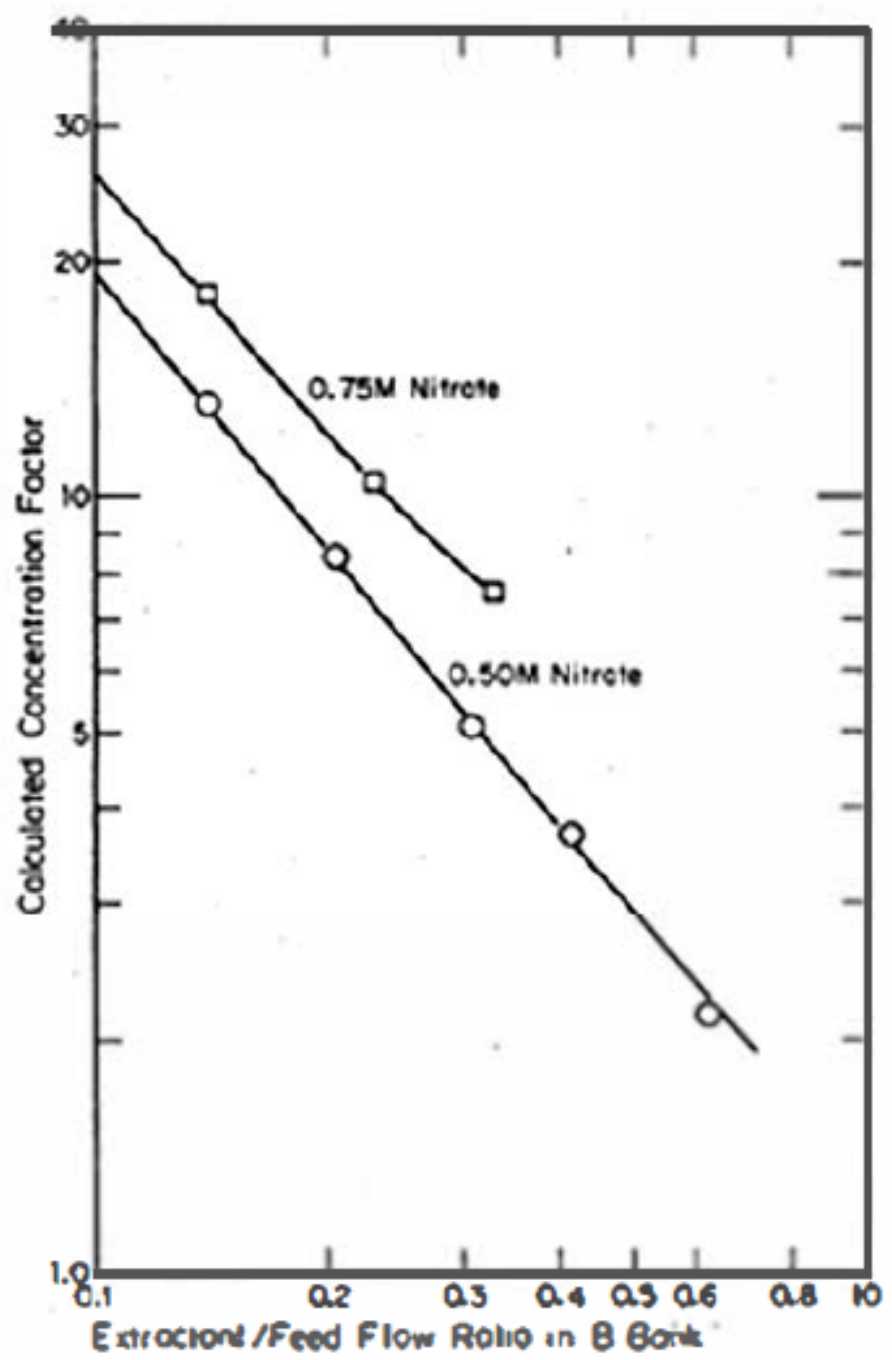

Figure 14. Plutonium concentration factors calculated by SEPHIS.

Concentration profiles (Figure 15) of $\mathrm{HNO}_{3}, \mathrm{U}, \mathrm{Pu}$, and Tc were measured in CETE Campaign 1 and in a previous PUREX process demonstration.

In CETE Campaign 1, the $\mathrm{U}$ and $\mathrm{Tc}$ that were not stripped in the second contactor bank were quantitatively stripped in the third contactor bank using dilute acid $\left(0.01 M \mathrm{HNO}_{3}\right)$. In addition, the third contactor bank was heated $\left(\sim 50^{\circ} \mathrm{C}\right)$ to improve the stripping efficiency. In CETE Campaign 2 , the Uloaded solvent was stored temporarily, and subsequently a special demonstration run was made to strip the U product. For both CETE campaigns, the unloaded organic solvent was discarded and not recycled. 


\section{Previous PUREX Demonstration}

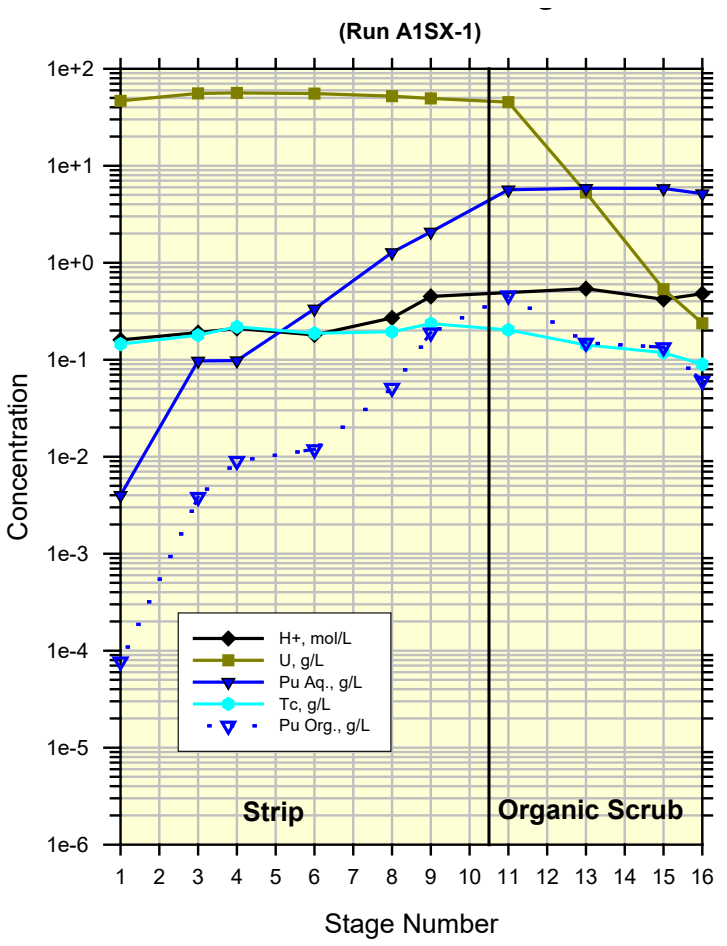

\section{CETE Campaign 1}

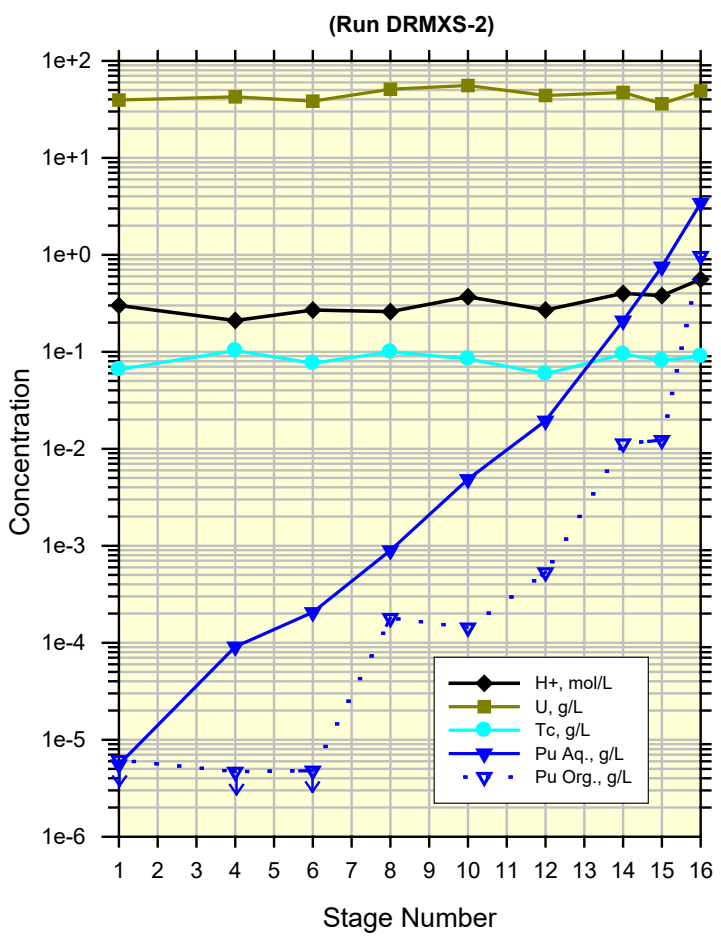

Figure 15. Measured concentration profiles for partitioning and partial partitioning contactor stages.

\subsubsection{Component Distribution and Co-Stripped U-Pu-Np Product Decontamination Factors}

End stream component distribution (Table 11) and U-Pu-Np product decontamination factors (Table 12) show the basic performance achieved with the UREX + Co-Decontamination - Partial Partitioning process when used in CETE Campaign 1 using relatively low-burnup, long-decayed BWR UNF compared to CETE Campaign 2 using high-burnup, relatively short-decayed PWR UNF. It is unfortunate that mass spectrometry analyses were not obtained in Campaign 2, thereby forcing performance from that campaign to be evaluated based on radiochemical analyses. 
Table 11. UREX co-decontamination-partial partitioning end stream component distribution.

\begin{tabular}{|c|c|c|c|c|c|c|c|c|c|c|}
\hline & \multicolumn{5}{|c|}{$\begin{array}{c}\text { CETE Campaign 1 } \\
\text { Dresden-1 BWR UNF } \\
24 \text { GWd/MT Burnup } \\
\text { 32-y Decayed }\end{array}$} & \multicolumn{5}{|c|}{$\begin{array}{c}\text { CETE Campaign } 2 \\
\text { North Anna PWR UNF } \\
\sim 65 \text { GWd/MT Burnup } \\
\text { 5-y Decayed }\end{array}$} \\
\hline & Feed & $\begin{array}{c}\text { FP } \\
\text { Raffinate }\end{array}$ & $\begin{array}{c}\text { U-Pu- } \\
\text { Np } \\
\text { Product }\end{array}$ & $\begin{array}{l}\text { Bulk U } \\
\text { Product }\end{array}$ & \begin{tabular}{|c|} 
Unloaded \\
Solvent
\end{tabular} & Feed & $\begin{array}{c}\text { FP } \\
\text { Raffinate }\end{array}$ & $\begin{array}{c}\text { Tc } \\
\text { Raffinate }\end{array}$ & $\begin{array}{c}\text { U-Pu- } \\
\text { Np } \\
\text { Product }\end{array}$ & \begin{tabular}{|c} 
Bulk U \\
in Solvent
\end{tabular} \\
\hline $\mathrm{U}$ & $2,950 \mathrm{~g}$ & $0.012 \%$ & $6.24 \%$ & $93.49 \%$ & $0.26 \%$ & $1,652 \mathrm{~g}$ & $0.003 \%$ & $0.004 \%$ & $2.8 \%$ & $95.10 \%$ \\
\hline $\mathrm{Pu}$ & $20.45 \mathrm{~g}$ & $0.011 \%$ & $99.88 \%$ & $0.105 \%$ & $0.005 \%$ & $24.5 \mathrm{~g}$ & $0.11 \%$ & $0.19 \%$ & $94.8 \%$ & $6.20 \%$ \\
\hline $\mathrm{Np}$ & $0.89 \mathrm{~g}$ & $<0.7 \%$ & $>98.8 \%$ & $<0.2 \%$ & $<0.2 \%$ & $1.65 \mathrm{~g}$ & $<0.9 \%$ & $0.15 \%$ & $126.7 \%$ & \\
\hline $\mathrm{Am}$ & $2.27 \mathrm{~g}$ & $99.98 \%$ & $0.0037 \%$ & $0.01 \%$ & $0.0006 \%$ & $1.78 \mathrm{~g}$ & $93.7 \%$ & $0.004 \%$ & $0.30 \%$ & $0.14 \%$ \\
\hline $\mathrm{Cm}-244$ & $0.031 \mathrm{~g}$ & $99.61 \%$ & $<0.02 \%$ & $0.30 \%$ & $0.07 \%$ & $0.52 \mathrm{~g}$ & $96.4 \%$ & $0.013 \%$ & & $0.01 \%$ \\
\hline $\begin{array}{l}\text { Actinide } \\
\text { Total }\end{array}$ & $2,973.6 \mathrm{~g}$ & & & & & $1,680.5 \mathrm{~g}$ & & & & \\
\hline $\mathrm{Y}$ & $1.02 \mathrm{~g}$ & $>99.95 \%$ & $<0.02 \%$ & $<0.02 \%$ & & & & & & \\
\hline $\mathrm{Zr}$ & $7.45 \mathrm{~g}$ & $99.77 \%$ & $<0.007 \%$ & $0.22 \%$ & & & & & & \\
\hline Mo & $6.68 \mathrm{~g}$ & $99.94 \%$ & $0.043 \%$ & $0.02 \%$ & & & & & & \\
\hline $\mathrm{Tc}$ & $1.12 \mathrm{~g}$ & $2.01 \%$ & $31.63 \%$ & $66.36 \%$ & & $0.122 \mathrm{~g}$ & $<75.0 \%$ & $526 \%$ & $<61 \%$ & $0.033 \%$ \\
\hline $\mathrm{Ru}$ & $0.49 \mathrm{~g}$ & $99.65 \%$ & $<0.05 \%$ & $0.29 \%$ & & & & & & \\
\hline Ru-106 & & & & & & $2.3 \mathrm{Ci}$ & $<230 \%$ & $0.111 \%$ & $<0.53 \%$ & $2.98 \%$ \\
\hline $\mathrm{Pd}$ & $0.009 \mathrm{~g}$ & $>98.1 \%$ & $<1.0 \%$ & $<0.8 \%$ & & & & & & \\
\hline $\mathrm{La}$ & $3.04 \mathrm{~g}$ & $99.92 \%$ & $0.024 \%$ & $0.05 \%$ & & & & & & \\
\hline $\mathrm{Ce}$ & $5.72 \mathrm{~g}$ & $99.96 \%$ & $<0.03 \%$ & $\sim 0.009 \%$ & & & & & & \\
\hline $\mathrm{Ce}-144$ & & & & & & $13.6 \mathrm{Ci}$ & $83.60 \%$ & $0.013 \%$ & $0.036 \%$ & $<0.003 \%$ \\
\hline $\operatorname{Pr}$ & $2.75 \mathrm{~g}$ & $99.98 \%$ & $<0.01 \%$ & $\sim 0.01 \%$ & & & & & & \\
\hline $\mathrm{Nd}$ & $9.98 \mathrm{~g}$ & $>99.99 \%$ & $<0.003 \%$ & $<0.002 \%$ & & & & & & \\
\hline $\mathrm{Sm}$ & $1.74 \mathrm{~g}$ & $>99.97 \%$ & $<0.02 \%$ & $<0.01 \%$ & & & & & & \\
\hline $\mathrm{Eu}$ & $0.29 \mathrm{~g}$ & $99.78 \%$ & $<0.10 \%$ & $0.12 \%$ & & & & & & \\
\hline Eu-154 & $0.935 \mathrm{Ci}$ & $>99.9 \%$ & $<0.008 \%$ & $0.02 \%$ & $<0.007 \%$ & $15.0 \mathrm{Ci}$ & $92.9 \%$ & $0.002 \%$ & $0.010 \%$ & $0.001 \%$ \\
\hline $\mathrm{Gd}$ & $0.36 \mathrm{~g}$ & $>99.9 \%$ & $<0.07 \%$ & $<0.06 \%$ & & & & & & \\
\hline $\mathrm{Cs}$ & $4.52 \mathrm{~g}$ & $>99.9 \%$ & $<0.06 \%$ & $<0.05 \%$ & & & & & & \\
\hline Cs-134 & & & & & & $105 \mathrm{Ci}$ & $90.3 \%$ & $0.0004 \%$ & $<0.001 \%$ & $<0.0001 \%$ \\
\hline Cs-137 & $110 \mathrm{Ci}$ & $100.00 \%$ & $\begin{array}{l}0.00009 \\
\%\end{array}$ & $0.002 \%$ & $\begin{array}{l}<0.00002 \\
\%\end{array}$ & $321 \mathrm{Ci}$ & $94.5 \%$ & $0.0004 \%$ & $0.0006 \%$ & $0.00003 \%$ \\
\hline $\mathrm{Ba}$ & $5.1 \mathrm{~g}$ & $99.79 \%$ & $<0.04 \%$ & $\sim 0.17 \%$ & & & & & & \\
\hline $\mathrm{Rb}$ & $0.23 \mathrm{~g}$ & $>99.2 \%$ & $<0.4 \%$ & $<0.3 \%$ & & & & & & \\
\hline $\mathrm{Sr}$ & $1.43 \mathrm{~g}$ & $99.74 \%$ & $<0.08 \%$ & $0.18 \%$ & & & & & & \\
\hline Sr-90 & $61 \mathrm{Ci}$ & & & & & $292 \mathrm{Ci}$ & & & & \\
\hline
\end{tabular}

Losses of $\mathrm{U}, \mathrm{Pu}$, and $\mathrm{Np}$ to the raffinate streams were reasonably low, perhaps a little higher in CETE Campaign 2 because the flowsheet included both a Tc raffinate and the normal $\mathrm{Am}-\mathrm{Cm}$-fission product raffinate. 
Product recovery of $\mathrm{Pu}$ and $\mathrm{Np}$ to the $\mathrm{U}-\mathrm{Pu}-\mathrm{Np}$ product solution were appropriately high in CETE Campaign 1, with low losses to other effluent streams. Recovery distributions measured for CETE Campaign 2 left some questionable conclusion for $\mathrm{Pu}$. The $\mathrm{U}$ product solution contained $6 \%$ of the $\mathrm{Pu}$ and the $\mathrm{Pu}$ mass balance was $\sim 100 \%$; however, $\mathrm{Np}$ recovery was all in the $\mathrm{U}-\mathrm{Pu}-\mathrm{Np}$ product solution. This situation is difficult to understand. Possibly, this effect was due to kinetics of the HAN reduction.

The $\mathrm{Pu}$ concentration in the $\mathrm{U}-\mathrm{Pu}-\mathrm{Np}$ product solution was $10 \%$ in CETE Campaign 1, sufficiently high to downblend to recycle fuel for LWRs. In Campaign 2, the Pu concentration in the U-Pu-Np product solution was $32 \%$, which was high enough to downblend to recycle fuel for fast reactors. In both campaigns, the Pu concentration factor was exponentially dependent on the aqueous/organic (A/O) flow ratio, so obtaining a precise $\mathrm{Pu}$ concentration was difficult without online measurement and feedback control. Subsequently, the 2016 Co-decontamination (CoDCon) Project led by PNNL (Ref. 15) was initiated to address this issue.

Table 12. UREX co-decontamination U-Pu-Np product decontamination factors. ${ }^{(a)}$

\begin{tabular}{|c|c|c|}
\hline \multicolumn{2}{|c|}{$\begin{array}{c}\text { CETE Campaign } 1 \\
\text { Dresden-1 BWR UNF } \\
24 \text { GWd/MT Burny } \\
32 \text { y decay }\end{array}$} & \multirow{2}{*}{$\begin{array}{c}\text { CETE Campaign } 2 \\
\text { North Anna PWR UNF } \\
\sim \mathbf{6 5} \text { GWd/MT Burnup } \\
\mathbf{5} \text { y decay } \\
34 \\
\end{array}$} \\
\hline $\mathrm{U}$ & 16 & \\
\hline $\mathrm{Am}$ & $2.7 \mathrm{E}+04$ & $3.3 \mathrm{E}+02$ \\
\hline $\mathrm{Cm}$ & $>5.0 \mathrm{E}+03$ & \\
\hline $\mathrm{Zr}$ & $>1.43 \mathrm{E}+04$ & \\
\hline $\mathrm{Tc}$ & 3.1 & $>1.5$ \\
\hline $\mathrm{Ru}$ & $>2.0 \mathrm{E}+02$ & $>1.8 \mathrm{E}+02$ \\
\hline $\mathrm{Ce}$ & $>3.3 \mathrm{E}+03$ & $2.6 \mathrm{E}+02$ \\
\hline${ }^{154} \mathrm{Eu}$ & $>1.2 \mathrm{E}+04$ & $>9.5 \mathrm{E}+03$ \\
\hline $\mathrm{Eu}$ & $>1.0 \mathrm{E}+03$ & \\
\hline${ }^{134} \mathrm{Cs}$ & & $>9.5 \mathrm{E}+04$ \\
\hline${ }^{137} \mathrm{Cs}$ & $1.1 \mathrm{E}+06$ & $1.6 \mathrm{E}+05$ \\
\hline \multirow[t]{2}{*}{ Cs } & $>1.7 \mathrm{E}+03$ & \\
\hline & (a) Based on $\mathrm{Pu}$ & \\
\hline
\end{tabular}

The decontamination factors obtained in CETE Campaign 2 (Table 12) were slightly lower than in Campaign 1, possibly due to the higher fuel burnup and greater radioactivity in the shorter-decayed fission products. However, the decontamination factors were satisfactory for Am and most fission products in both campaigns, with the exception of Tc. Moreover, the sample analyses for Tc were inconsistent.

Earlier, results (Table 7) from the fuel dissolutions in $\mathrm{HNO}_{3}$ showed that about half of the predicted amount of Tc in the fuel was dissolved and half was in the UDS during CETE Campaign 1, but more than half was in the UDS from the higher burnup UNF processed in Campaign 2 . In Campaign 1, 30\% of the soluble Tc was found in the U-Pu-Np product solution (Table 11), possibly due to the reducing conditions with excess HAN in the stripping reagent, and $\sim 60 \%$ was in the bulk U product. Thus, both product solutions would have had to be purified in additional separate operations to remove the Tc from recycle fuels. 
Therefore, in CETE Campaign 2 the flowsheet (Figure 12) was changed to add an extra high-acidity Tc scrub to remove Tc from the $\mathrm{U}-\mathrm{Pu}-\mathrm{Np}$-loaded solvent before the stripping contactor banks. That objective may have been achieved, but analysis results (Table 11) were not consistent (the feed solution showed a much lower amount than found in the effluent solutions). In addition, interim analyses during the operation showed most of the $\mathrm{Tc}$ in the $\mathrm{U}-\mathrm{Pu}-\mathrm{Np}$ product stream, whereas at the end of the operation, most of the Tc was found in the Tc raffinate where it was intended to go. Thus, the results were inconsistent and created doubt about whether the desired effect was achieved.

\section{PRODUCT CONVERSION AND PELLET FABRICATION}

\subsection{MODIFIED DIRECT DENITRATION PROCESS AND EQUIPMENT}

Both product nitrate solutions (U-Pu-Np and U) from the CETE campaigns were converted to oxide powder by means of the modified direct denitration (MDD) process, a modified thermal denitration process developed at ORNL [Ref. 16] in the early 1980s during the CFRP. However, no data were collected during CETE Campaign 2. Therefore, the specific process conditions and product characterization data are based on the CETE Campaign 1 products. Moreover, the primary emphasis is on the U-Pu-Np product, which, inadvertently, contained about one-third of the fission product technetium (Tc).

The MDD process was developed as an improved method for converting $U$, or actinide elements, or combinations of these metal nitrates to oxides or mixed oxides with good ceramic properties for fabrication of recycle fuels [Refs. 17, 18]. A similar process is used in the French LaHague plant for conversion of minor actinides and fission products to mixed oxides before vitrification (Ref. 19).

The MDD process uses simple process equipment, a rotary kiln reactor, which is continuously fed with nitrate solution and continuously discharges product oxide powder. The design of the kiln, which is basically a straight length of stainless steel tubing with a diameter selected for the capacity of oxide production needed. Dimensions of the design can be selected to enable subcritical operation with highly fissile materials. The small-size $(\sim 100 \mathrm{~g} / \mathrm{h})$ kiln and accessory equipment used in the CETE campaigns is shown in Figure 16.

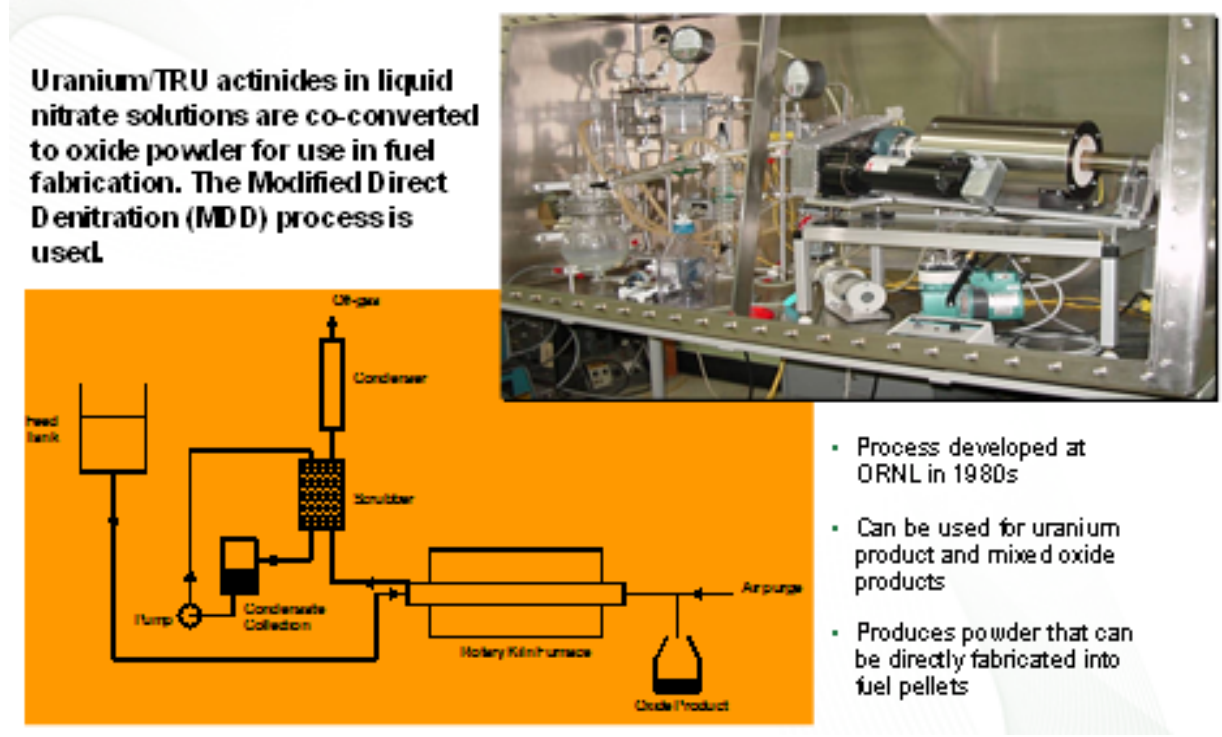

Figure 16. Co-conversion of $\mathrm{U}-\mathrm{Pu}-\mathrm{Np}$ and $\mathrm{U}$ product nitrates. 
Before entering the MDD kiln, ammonium nitrate is added to the metal nitrate solution to form an ammonium metal nitrate double salt, which modifies the thermal denitration reaction to produce a flowable oxide, or mixed oxide powder with mean particle size of about $5 \mu \mathrm{m}$, and surface area of 5$10 \mathrm{~m}^{2} / \mathrm{g}$. These powder morphology characteristics are a major improvement to the direct thermal denitration process, which forms a mastic phase during the denitration and large-size $(40-50 \mu \mathrm{m}$ diameter) particles requiring post-reaction grinding to obtain a flowable powder (Ref. 16).

The gaseous effluent from the kiln is passed through a scrubber and condenser to collect entrained solids and absorbed $\mathrm{NO}_{2}$ as recycle $\mathrm{HNO}_{3}$. Non-condensable $\mathrm{NO}_{\mathrm{x}}$ is released to the off-gas system.

\subsection{PROCESSING CONDITIONS}

The U-Pu-Np product nitrate solution from the UREX+ Co-decontamination - Partial Partitioning solvent extraction demonstration run of CETE Campaign 1 was treated (1) to remove the residual organic extractant by diluent washing with normal-paraffin hydrocarbon solution, (2) to remove residual HAN by sparging with $\mathrm{NO}$ gas, then (3) concentrated $\sim 10$-fold by evaporation to remove excess acid and increase the metals concentration. Ammonium nitrate was added to provide a mole ratio of $\mathrm{NH}_{4} /$ metals of $\sim 2$.

There was a significant difference in the analyses of components before and after the diluent washing and 10 -fold high acidity evaporation feed adjustment steps. These analyses showed that $35 \mathrm{wt} . \%$ of the Pu and 10 wt.\% of the U, Np, and Am disappeared during the feed adjustment steps. Losses would not be expected to occur during high acidity operations. The reason for this discrepancy was not resolved.

The adjusted MDD feed metals concentration was $\sim 250 \mathrm{~g} / \mathrm{L}$, the $\mathrm{HNO}_{3}$ concentration was $\sim 5 \mathrm{~N}$ free acid, and the total nitrate concentration was $\sim 9 M$. This feed solution was fed to the kiln at $\sim 5 \mathrm{~mL} / \mathrm{min}$, and countercurrent air flow rate was about $9 \mathrm{~L} / \mathrm{min}$. The furnace temperature was set at $675^{\circ} \mathrm{C}$ to enable the maximum endothermic denitration temperature for $\mathrm{U}$ of $\sim 350^{\circ} \mathrm{C}$. A three-point thermocouple inserted from the product oxide discharge end of the kiln was used to measure the centerline heated pipe internal temperature in the rotary kiln. At steady state, the temperature profile (from feed to middle to product end) was $175 / 540 / 510^{\circ} \mathrm{C}$.

To maximize the product produced under steady-state conditions, a decision was made to begin the run by feeding ammonium-uranyl nitrate double salt solution that was obtained from the UREX+Codecontaminating - Partial Partitioning of the U product (which contained about 2/3 of the fission product Tc) until steady-state operation was achieved. Steady-state is reached when the temperature profile measured inside the middle of the rotary kiln heated pipe is constant. At that time, the feed was switched to the $\mathrm{U}-\mathrm{Pu}-\mathrm{Np}$ product solution and collection of the steady-state product oxide was begun $\sim 25$ min after switching the feed solution. This was done to collect only the steady-state U-Pu-Np oxide product. Operating in this manner led to a reduction of the Pu concentration in the product.

\subsection{CONVERSION RESULTS}

The amount of mixed oxide product collected was $185.4 \mathrm{~g}$, and the measured U/Pu ratio was 13.7. A sample of the mixed oxide product was heated on a hot plate to determine the volatiles content. After heating to $290^{\circ} \mathrm{C}$ for 0.5 hour, the weight loss was $3 \%$. After heating further to $>300^{\circ} \mathrm{C}$ (maximum readout on the thermometer) for another hour, the weight loss was $4.5 \%$. The larger weight loss was attributed to conversion of some of the $\mathrm{UO}_{3}$ to $\mathrm{U}_{3} \mathrm{O}_{8}$. The entire product was then sieved to -40 mesh. No other mechanical operation was performed on the powder. The product bulk and tap densities were measured as 0.76 and $0.94 \mathrm{~g} / \mathrm{mL}$, respectively. A photograph of the product powder is shown in Figure 17. 


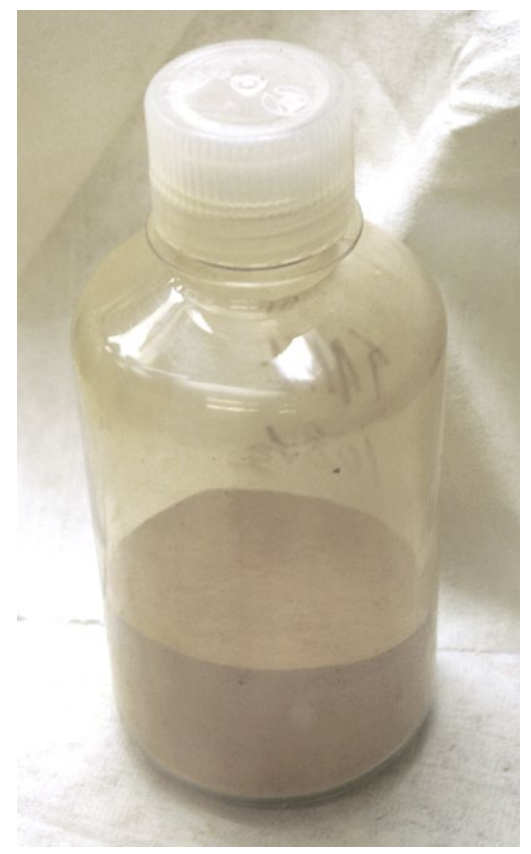

Figure 17. MDD-produced U-Pu-Np oxide from CETE Campaign 1.

Condensable vapors and any product entrained in the air purge were collected in the condensate/scrubber pot. This solution was analyzed to determine that the losses were $0.4 \% \mathrm{U}$, and $0.01 \% \mathrm{Pu}$. Unfortunately, Tc was not measured in the scrubber solution and some of the contained Tc may have been volatilized. The Tc concentration in the adjusted feed solution, as measured by inductively coupled plasma mass spectrometry, was $\sim 1,900 \mu \mathrm{g} / \mathrm{g} \mathrm{U}$, and only $1,170 \mu \mathrm{g} / \mathrm{g} \mathrm{U}$ in the product oxide.

The ratio of uranium to plutonium being higher in the product in comparison to the feed was attributed to starting the run by feeding the bulk $U$ product to achieve steady state prior to switching the feed to the U$\mathrm{Pu}-\mathrm{Np}$ product. Thus, a comparable increase in the $\mathrm{U}$ to $\mathrm{Pu}-\mathrm{Np}$ mass ratio was observed. Some dilution of the product with materials remaining in the kiln from earlier runs was possible because the typical holdup in the kiln is $5-15 \mathrm{~g}$ of oxide.

\subsection{REDUCTION OF UO ${ }_{3}$, PELLET PRESSING, AND SINTERING}

To provide feedback to MDD process development as to the suitability of the MDD powder for pellet fabrication, the U-Pu-Np oxide product was sieved to -40 mesh and a $10.42 \mathrm{~g}$ sample was calcined/reduced (converting $\mathrm{UO}_{3}$ to $\mathrm{UO}_{2}$ ) for pressing into pellets. Four green pellets were fabricated. Two of these pellets were sintered and inspected.

The calcination/reduction was performed in a $4 \% \mathrm{H}_{2} / \mathrm{Ar}$ atmosphere at $600^{\circ} \mathrm{C}$ for 4 hours. Complete conversion of the $\mathrm{UO}_{3}$ to $\mathrm{UO}_{2}\left(\mathrm{UO}_{3}+\mathrm{H}_{2} \rightarrow \mathrm{UO}_{2}+\mathrm{H}_{2} \mathrm{O}\right)$ was confirmed by X-ray diffraction analysis using a Rigaku powder X-ray diffractometer housed in a glovebox. Bulk and tap densities of the reduced oxide were measured as 0.90 and $1.15 \mathrm{~g} / \mathrm{mL}$, respectively. Figure 18 is a scanning electron microscope (SEM) image of the reduced powder showing a microstructure similar to $\mathrm{UO}_{2}$ originating from ammonium diuranate-produced $\mathrm{UO}_{2}$ which is shown in [Ref. 20]. 


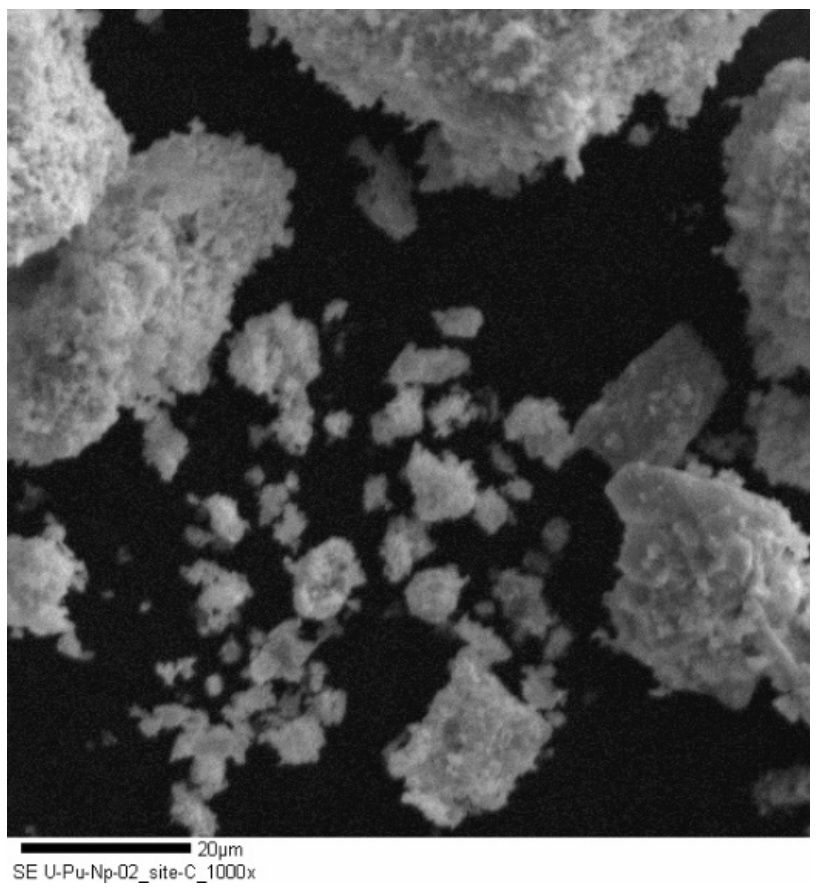

Figure 18. SEM image of reduced MDD U-Pu-Np Product at 1,000 $\times$ magnification.

Stearic acid $(0.3 \mathrm{wt} . \%)$ was added to the reduced mixed oxide as a die lubricant for pellet pressing. This mixture was poured into a die and pressed to $\sim 43,000$ psi using a single-action, downward press. The green pellets (Figure 19) held together well over time and showed no cracks or signs of flaking.

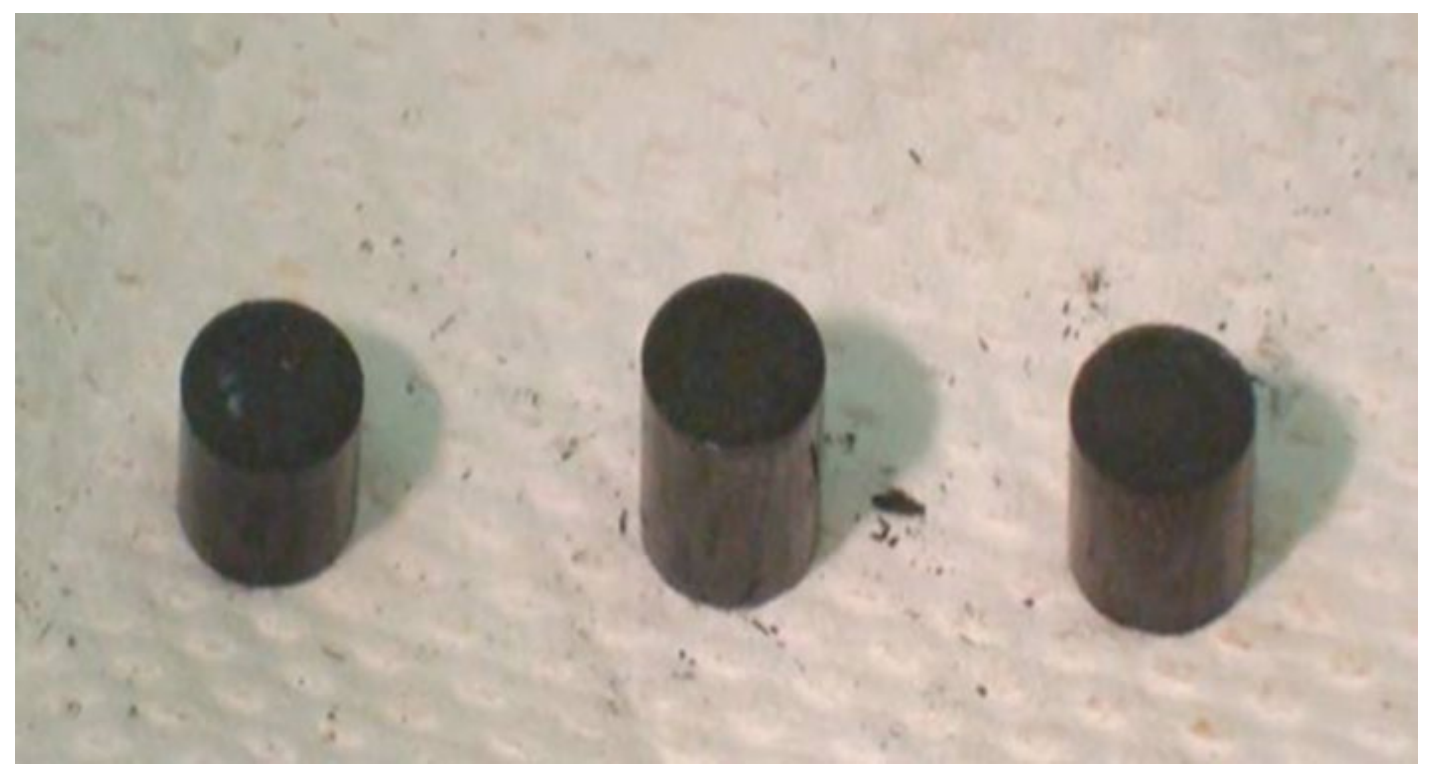

Figure 19. Dresden-1 U-Pu-Np mixed oxide green pellets.

Two of the pellets were sintered in a $4 \% \mathrm{H} / \mathrm{Ar}$ atmosphere. The sintering temperature profile was (1) heat to $300^{\circ} \mathrm{C}$ at $2^{\circ} \mathrm{C} / \mathrm{min}$; (2) hold for $30 \mathrm{~min}$; (3) heat from $300^{\circ} \mathrm{C}$ to $1,400^{\circ} \mathrm{C}$ at $5^{\circ} \mathrm{C} / \mathrm{min}$; (4) hold for 4 
hours; then (5) cool to $20^{\circ} \mathrm{C}$ at a rate of $25^{\circ} \mathrm{C} / \mathrm{min}$. The maximum sintering temperature in the available furnace was $\sim 1,400^{\circ} \mathrm{C}$, rather than the typical $1,700-1,750^{\circ} \mathrm{C}$ for standard mixed oxide containing $\mathrm{Pu}$. Table 13 summarizes the results of the pellet pressing and sintering.

Table 13. Pressed and sintered pellets results.

\begin{tabular}{|c|c|c|c|c|}
\hline \multicolumn{2}{|c|}{ Pellet Designation } & $\begin{array}{c}\text { Diameter } \\
\text { (in.) }\end{array}$ & L/D & \% TD* \\
\hline$\# 1$ & Green & 0.2530 & 0.84 & 48.7 \\
\hline \multirow{2}{*}{$\# 2$} & Green & 0.2530 & 1.00 & 48.2 \\
\cline { 2 - 5 } & Sintered & 0.2005 & 1.00 & 94.8 \\
\hline \multirow{2}{*}{$\# 3$} & Green & 0.2530 & 1.18 & 48.4 \\
\cline { 2 - 5 } & sintered & 0.2015 & 1.18 & 92.7 \\
\hline$\# 4$ & green & 0.2530 & 1.00 & 48.6 \\
\hline
\end{tabular}

* Theoretical Density (TD) was calculated assuming the presence of $\mathrm{UO}_{2}$, $\mathrm{PuO}_{2}$, and $\mathrm{NpO}_{2}$, as well as the impuritiy $\mathrm{TcO}_{2}$, and minor impurities.

\subsection{PELLET MICROSTRUCTURAL CHARACTERIZATION}

The two sintered pellets with 94.8\% TD and 92.7 TD (Table 13) were selected for microstructural examination. The initial characterization effort included mounting, polishing, optical microscopy, and SEM. The pellets were epoxy potted in separate mounts, then rough ground to the midplane. One pellet was oriented axially and the other radially. Additional epoxy was added after the rough grinding to minimize pullout. Each mount was polished with progressively finer grit paper then with a $3 \mu \mathrm{m}$ slurry and $1 \mu \mathrm{m}$ polishing cloth. An array of digital image sections was captured and a composite image was assembled of each pellet. Higher magnification was used to examine specific details.

Microstructures of the axial and radial cross sections of the sintered MDD pellets are shown in Figure 20.
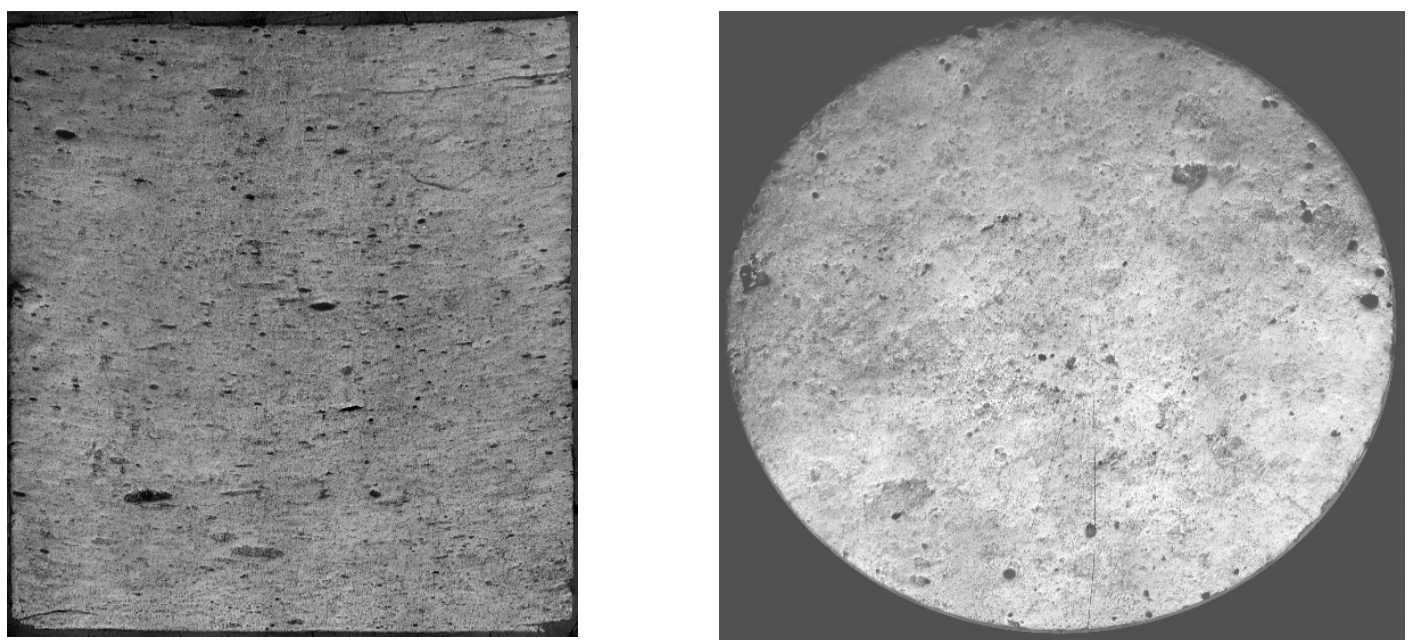

Figure 20. Axial (left) and radial (right) cross sections of sintered MDD pellets.

The microstructure was characterized by spherical and lenticular-shaped features that ranged in size from 10 to $5 \mu \mathrm{m}$ and had widely distributed sub-micrometer size pores. The large lenticular pores were 
indicative of stress gradients resulting from residual pressing stria and low-temperature microsintering. End cap and laminar cracks were visible in the longitudinal section of Figure 21. Cracking was minimal, which is an indication that the feedstock powder had good flow ability characteristics; however, powder processing improvements are needed to minimize residual stress and "springback" in the powder compact. Some heterogeneity in the microstructure was evident, but the source was unclear.

Microsintering was likely typified by the onset of particle-to-particle necking, fine porosity, and minimal grain growth (Figure 21). The starting powder has a fine grain structure with good surface area for sintering. At $1,400^{\circ} \mathrm{C}$, the oxygen mobility was high and there was some cation transport. SEM analysis revealed that large spherical and oblong features are regions of pullout. There was evidence of a second amorphous phase in the area around the pullout that resulted in a locally weakened microstructure. A low$\mathrm{Z}$ second phase was observed (possibly $\mathrm{Tc}_{2} \mathrm{O}_{7}$ ).

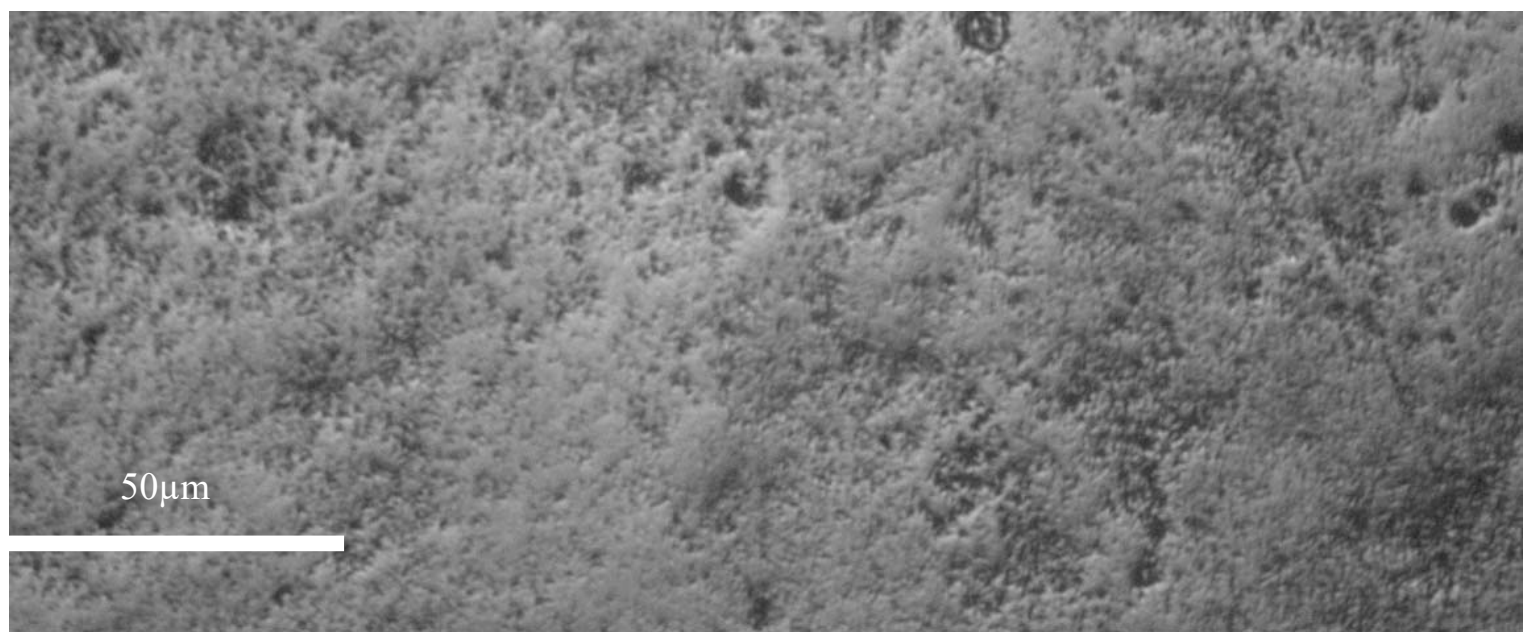

Figure 21. Sintered fine microstructure.

The MDD powder had desirable attributes for sintering, with fine grain-size powder that had a high surface energy and a sintered microstructure that had tortuous boundaries that aided in stress relief. The onset of densification occurred at relatively low temperatures, but the grain growth at sintering temperature, especially less than $1,500^{\circ} \mathrm{C}$, was minimal. Future irradiation performance criteria, such as microstructural stability, fuel swelling, and fission product retention, may dictate a preferred minimum grain size, and thus set the sintering time and temperature.

\section{SUMMARY}

Building on extensive R\&D and demonstrations with actual LWR and fast reactor spent fuels, the CETE campaigns described above provided comprehensive results from both low- and high-burnup spent fuels, long and short decay periods before processing, spent fuels from a BWR and a PWR for comparison of performance. These demonstrations bracketed spent fuels produced today. In addition, early designs and testing of processing and handling equipment were made and provided insight about further improvements that are needed.

The voloxidation process to remove tritium and potentially other volatile fission products before subsequent aqueous processing was demonstrated in both campaigns, first with preliminary equipment to discover potential problems in handling and scale-up, and then with a more appropriate and multikilogram scale, stainless steel voloxidation reactor. Early application of off-gas trapping equipment 
and performance was obtained, and these results are described in a separate report. The future need for converting to a continuously fed and product discharge, such as a rotary kiln reactor, was identified.

Dissolution of the $\mathrm{U}_{3} \mathrm{O}_{8}$ powder product from voloxidation was demonstrated and compared with the two types of spent fuel and with ORIGEN predictions. Subsequent studies to measure and compare the amounts and composition of the undissolved solids were enabled by the demonstration runs. Some measurements of dissolver off-gas components and trapping capability were enabled.

Compositions of the spent fuel claddings were made and enabled a subsequent project to purify the different types of cladding to remove embedded radioactivity and enable disposal as low-level waste, rather than requiring much more expensive disposal in a deep geologic repository; in addition, the demonstrations enabled development of purification methods to recycle the zirconium, which represents $\sim 25 \%$ of the mass of spent fuel components.

The demonstrations provided further comparisons of the solvent extraction flowsheet for the UREX+Codecontamination - Partial U Partitioning process, including decontamination from minor actinides (Am and $\mathrm{Cm}$ ) and most fission product elements. The distribution of the co-extracted fission product, technetium, was enabled, first without special treatment, and then with a special high acidity scrubbing operation.

Finally, MDD process performance data was obtained from the first CETE campaign on conversion of the $\mathrm{U}-\mathrm{Pu}-\mathrm{Np}$ nitrate co-product solution to a mixed oxide powder with good ceramic properties for fabrication of recycle fuel pellets. A demonstration of the $\mathrm{UO}_{3}$ reduction to $\mathrm{UO}_{2}$ in the mixed oxide, followed by pressing, sintering, and characterization of the mixed oxide pellets was done.

\section{REFERENCES}

1. L. K. Felker, J. L. Binder, D. E. Benker, E. D. Collins, P. D. Bailey, G. L. Bell, R. T. Jubin, R. J. Vedder, E. A. Walker, and S. L. Voit, Results, Evaluation, and Lessons Learned from the Coupled End-to-End Project Campaign 1 Using Dresden BWR Used Fuel, GNEP-SEPA-PMO-M1-DV-2008000131, (June 2008, reissued as ORNL/TM-2020/1712, (October 2020).

2. D. E. Benker and E. D. Collins, ORNL Report on Additional Radiochemical Analysis of Archived Samples, ORNL Fuel Cycle Research and Development Milestone Report 3502030909 (June 2010).

3. E. D. Collins and D. E. Benker, IODOX Tests in a Transuranium Element Production Campaign, ORNL/TM-6182 (1978).

4. E. D. Collins, D. E. Benker, J. E. Bigelow, F. R. Chattin, M. H. Lloyd, L. J. King, R. G. Ross, and H. C. Savage, Solvent Extraction Studies of Coprocessing Flowsheets-Results from Campaigns 1 and 2 of the Solvent Extraction Test Facility (SETF), ORNL/TM-7080 (July 1982).

5. D. E. Benker, J. E. Bigelow, W.D. Bond, F. R. Chattin, L. J. King, F.G. Kitts, R. G. Ross, and R. G. Stacy, Solvent Extraction Studies with High-Burnup Fast Flux Test Facility Spent Fuel in the Solvent Extraction Test Facility, ORNL/TM-9993 (October 1986).

6. E. D. Collins, D. E. Benker, B. B. Spencer, P. Baron, B. Binh, W. D. Bond, and D. O. Campbell, "Development of the UREX+ Codecontamination Solvent Extraction Process," Proceedings of Global 2003 International Conference, American Nuclear Society, New Orleans (November 2003).

7. B. B. Spencer, G. D. Del Cul, R. T. Jubin, P. D. Bailey, R. S. Owens, D. W. Ramey, and E. D. Collins, Voloxidation Processing of CETE Run 2 Fuels: Experimental Results, ORNL/TM-2009/207 (drafted in March 2009). Reissued as ORNL/TM-2020/ (October 2020). 
8. T. S. Rudisill, L. C. Olson, and D. P. DiPrete, "Characterization of undissolved solids from dissolution of North Anna reactor fuel," Separations Science and Technology, 53-12, 1906-1917, DOI: $10.1080 / 01496325.2017 .1288138$.

9. B. E. Lewis, A Review of Solid/Liquid Separation Methods and Procedures for Fuel Reprocessing, ORNL/TM-7968 (July 1982).

10. C. Eysseri et al, "Examination and Characterization Methods Applied to Irradiated Fuel Claddings in the Atalante Facility", Proceedings of 2012 Atalante Conference, Procedia Chemistry, Elsevier, LTD (Sept. 2012)

11. E. Collins, B. Del Cul, B. Spencer, R. Brunson, and J. Johnson, "Establishment of the Roadmap for Chlorination Process Development for Zirconium Recovery and Recycle", Proceedings of the Global 2013 International Nuclear Fuel Cycle Conference (Oct 2013).

12. E. D. Collins, D. E. Benker, J. E. Bigelow, F. R. Chattin, L. J. King, R. G. Ross, and H. C. Savage, Solvent Extraction Studies of Coprocessing Flowsheets-Results from Campaigns 3 and 4 of the Solvent Extraction Test Facility (SETF), ORNL/TM-7991 (May 1982).

13. M. C. Thompson, M. A. Norato, G. F. Kessinger, R. A. Pierce, T. S. Rudisill, and J. D. Johnson, Demonstration of the UREX Solvent Extraction Process with Dresden Reactor Fuel Solution, WSRCTR-2002-00444 (September 2002).

14. M. S. Okamoto and M. C. Thompson, "Coprocessing solvent extraction studies," Nuclear Technology, Vol. 43, pp. 126-131, (Mid-April 1979)

15. G. J. Lumetta et al, “CoDCon Project: Design of the Phase 1 Testing System"”, PNNL-26173, Pacific Northwest National Laboratory, Richland, WA (2017).

16. E. D. Collins, "Advanced thermal denitration conversion processes for aqueous-based reprocessing and recycling of spent nuclear fuels," Chapter 12, pp. 313-323 in Reprocessing and Recycling of Spent Nuclear Fuel, edited by Robin Taylor, Woodhead Publishing Series in Energy: Number 79, Elsevier (2015).

17. L. K. Felker, R. J. Vedder, E. A. Walker, "Preparation of mixed oxides by modified direct denitration," American Nuclear Society Winter Meeting 2006, Albuquerque, NM.

18. L. K. Felker, R. J. Vedder, R. R. Brunson, E. D. Collins, "Plutonium and neptunium conversion using modified direct denitration," Eighth Information Exchange Meeting on Actinide and Fission Product Partitioning and Transmutation Abstract, November 2004, Las Vegas, NV.

19. J. Bruziere, E. Chauvin, J. Prioux, "World first in high level vitrification-a review of French vitrification industrial achievements", Proceedings of Global 2013 International Conference (October 2013)

20. H. Yoshimochi et al, "Fab. Technique for MOX Fuel Containing $\mathrm{AmO}_{2}$ by an In-cell Remote Process”, J. Nuc. Sci. \& Tech.., Vol. 41, No.8, p. 850-856 (Aug. 2004) 
